\title{
Climatology of aerosol optical properties and black carbon mass absorption cross section at a remote high-altitude site in the western Mediterranean Basin
}

\author{
M. Pandolfi, A. Ripoll, X. Querol, and A. Alastuey \\ Institute of Environmental Assessment and Water Research (IDAEA-CSIC), Barcelona, Spain \\ Correspondence to: M. Pandolfi (marco.pandolfi@idaea.csic.es) \\ Received: 3 December 2013 - Published in Atmos. Chem. Phys. Discuss.: 11 February 2014 \\ Revised: 19 May 2014 - Accepted: 20 May 2014 - Published: 27 June 2014
}

\begin{abstract}
Aerosol light scattering $\left(\sigma_{\mathrm{sp}}\right)$, backscattering $\left(\sigma_{\mathrm{bsp}}\right)$ and absorption $\left(\sigma_{\mathrm{ap}}\right)$ were measured at Montsec (MSC; $42^{\circ} 3^{\prime} \mathrm{N}, 0^{\circ} 44^{\prime} \mathrm{E}, 1570 \mathrm{~m}$ a.s.l.), a remote highaltitude site in the western Mediterranean Basin. Mean $( \pm \mathrm{SD}) \sigma_{\mathrm{sp}}, \sigma_{\mathrm{bsp}}$ and $\sigma_{\mathrm{ap}}$ were $18.9 \pm 20.8,2.6 \pm 2.8$ and $1.5 \pm 1.4 \mathrm{Mm}^{-1}$, respectively at $635 \mathrm{~nm}$ during the period under study (June 2011-June 2013). Mean values of singlescattering albedo (SSA, $635 \mathrm{~nm}$ ), the scattering Ångström exponent (SAE, $450-635 \mathrm{~nm}$ ), backscatter-to-scatter ratio $(B / S, 635 \mathrm{~nm})$, asymmetry parameter $(g, 635 \mathrm{~nm})$, black carbon mass absorption cross section (MAC, 637 nm) and $\mathrm{PM}_{2.5}$ mass scattering cross section (MSCS, $635 \mathrm{~nm}$ ) were $0.92 \pm 0.03,1.56 \pm 0.88,0.16 \pm 0.09,0.53 \pm 0.16$, $10.9 \pm 3.5 \mathrm{~m}^{2} \mathrm{~g}^{-1}$ and $2.5 \pm 1.3 \mathrm{~m}^{2} \mathrm{~g}^{-1}$, respectively. The scattering measurements performed at MSC were in the medium/upper range of values reported by Andrews et al. (2011) for other mountaintop sites in Europe due to the frequent regional recirculation scenarios (SREG) and Saharan dust episodes (NAF) occurring mostly in spring/summer and causing the presence of polluted layers at the MSC altitude. However, the development of upslope winds and the possible presence of planetary boundary layer air at MSC altitude in summer may also have contributed to the high scattering observed. Under these summer conditions no clear diurnal cycles were observed for the measured extensive aerosol optical properties $\left(\sigma_{\mathrm{sp}}, \sigma_{\mathrm{bsp}}\right.$ and $\left.\sigma_{\mathrm{ap}}\right)$. Conversely, low $\sigma_{\mathrm{sp}}$ and $\sigma_{\mathrm{ap}}$ at $\mathrm{MSC}$ were measured during Atlantic advections (AA) and winter regional anticyclonic episodes (WREG) typically observed during the cold season in the western Mediterranean. Therefore, a season-dependent decrease in the magnitude of aerosol extensive properties was observed when MSC was in the free troposphere, with
\end{abstract}

the highest free-troposphere vs. all-data difference observed in winter and the lowest in spring/summer. The location of MSC station allowed for a reliable characterization of aerosols as a function of the main synoptic meteorological patterns. The SAE was the lowest during NAF and showed an inverse correlation with the outbreak intensity, indicating a progressive shift toward larger particles. Moreover, the strength of NAF episodes in the region led to a slope of the scattering vs. absorption relationship among the lowest reported for other mountaintop sites worldwide, indicating that MSC was dominated by dust aerosols at high aerosol loading. As a consequence, SSA showed a nearly monotonic increase with increasing particle concentration and scattering. The SAE was the highest during SREG, indicating the presence of polluted layers dominated by smaller particles. Correspondingly, the asymmetry parameter was lower under SREG compared with NAF. The MAC and MSCS were significantly higher during NAF and SREG compared to AA and WREG, indicating an increase of absorption and scattering efficiencies associated with the summer polluted scenarios. The optical measurements performed at the MSC remote site were compared with those simultaneously performed at a regional background station in the western Mediterranean Basin located at around $700 \mathrm{~m}$ a.s.l. upstream of the MSC station.

\section{Introduction}

Atmospheric aerosols affect the Earth's radiative balance directly, by scattering and absorbing solar and terrestrial radiation, and indirectly, by acting as cloud condensation 
nuclei, thus modifying the physical and optical properties of clouds. The measurements of aerosol optical properties such as scattering, backscattering, absorption and extinction are important for aerosol characterization and model validation and, consequently, for a better comprehension of the role of aerosols in the Earth-atmosphere system (IPCC, 2007, 2013). Specific aerosol optical parameters such as singlescattering albedo (SSA), the scattering Ångström exponent (SAE), backscatter-to-scatter ratio $(B / S)$ and asymmetry parameter $(g)$, among others, can be derived from these optical properties. Moreover, the mass scattering cross section (MSCS) and the mass absorption cross section (MAC) of sampled aerosols can be obtained from independent measurements of particulate matter (PM) and elemental carbon (EC) concentrations, respectively, and the measured aerosol scattering and absorption coefficients. The cooling or absorbing potential of atmospheric aerosols mostly depends on these parameters, which are complex functions of aerosols size, shape, chemical composition and refractive index. Most particles scatter the sunlight, causing a net cooling at the top of the atmosphere, whereas black carbon (BC) particles (or EC) absorb radiation over the entire visible spectrum, thus affecting the vertical heating profile and causing a net warming of the Earth-atmosphere system (IPCC, 2007, 2013). BC particles play a role second only to carbon dioxide in climate change and are co-emitted with a variety of other aerosols and precursor gases which can increase the light absorption by $\mathrm{BC}$ through an increase in its MAC (e.g. Bond et al., 2013). Given that atmospheric models convert the modelled $\mathrm{BC}$ mass concentrations to optical absorption using the MAC, accurate estimates of MAC values and of the possible reasons explaining their variability are important.

Aerosol optical measurements are carried out worldwide by means of both in situ and remote techniques. In order to address the uncertainties related to the geographical variation in aerosols optical properties, networks such as ACTRIS (Aerosols, Clouds, and Trace gases Research InfraStructure Network, www.actris.net) or NOAA's baseline observatory (http://www.esrl.noaa.gov/gmd/) were created. The ACTRIS network aims at integrating three existing European research infrastructures: EUSAAR (European Supersites for Atmospheric Aerosol Research, for in situ aerosol measurements at regional level; www.eusaar.net), EARLINET (European Aerosol Research Lidar Network, for remote aerosol measurements; www.earlinet.org) and CLOUDNET (to provide a systematic evaluation of clouds in forecast models, www. met.rdg.ac.uk/radar/cloudnet/). Thus, the ACTRIS project provides the unique opportunity to integrate in situ and vertical aerosol measurements for the characterization of both the planetary boundary layer (PBL) and the free troposphere (FT). The measurements of aerosols in the FT are especially important given that FT aerosols are more spatially representative of the global atmosphere than the aerosols in the PBL due to their long residence time (of the order of several weeks). Aerosols in the FT can be transported over long dis- tances and have extended climate and air quality impacts (Laj et al., 2009; Andrews et al., 2011). Due to the location of the majority of in situ ACTRIS stations, the in situ measurements are performed mainly within the PBL, whereas the vertical lidar measurements allow for aerosol optical measurements almost in the whole troposphere. However, lidars do not measure key climate variables such as aerosol absorption, SSA, MSCS or MAC. Consequently, the measurements performed at mountaintop observatories provide the opportunity to make long-term, continuous observations of in situ aerosol properties in the free troposphere (FT). Moreover, given their frequent position in the FT, mountaintop stations give the possibility to study aerosols under different atmospheric scenarios without strong interference from closer anthropogenic emissions. However, the number of mountaintop observatories providing long-term in situ aerosol optical measurements worldwide is rather low. Recently, Andrews et al. (2011) presented climatology for free-tropospheric aerosol radiative properties utilizing in situ data from 10 high-altitude stations in the $20-50^{\circ} \mathrm{N}$ latitude band. Examples of high-altitude aerosol optical measurements were presented by Bodhaine (1983, 1995), McKendry et al. (2011), Marcq et al. (2010), Collaud Coen et al. (2004, 2007, 2011), Cozic et al. (2008), Andrews et al. (2011), Nyeki et al. (1998).

In this work we present the results from two-year measurements (June 2011-June 2013) of aerosol optical properties performed at the high-altitude Montsec station (MSC), which is run following the ACTRIS standards. Data from MSC were compared with data collected at the ACTRIS Montseny station (MSY; $41^{\circ} 19^{\prime} \mathrm{N}, 02^{\circ} 21^{\prime} \mathrm{E}, 720 \mathrm{~m}$ a.s.l.): a regional background station located around $140 \mathrm{~km}$ east of MSC. Seasonal and diurnal variation of extensive (scattering, absorption, extinction) and intensive (SSA, SAE, $B / S$, and $g$ ) aerosol properties as well as MSCS and MAC are presented and discussed. The effects of four main seasondependent synoptic atmospheric scenarios affecting the western Mediterranean Basin (WMB) on the measured optical properties are also discussed. Moreover, the data collected when the MSC station is in the FT are compared with the free-tropospheric aerosol optical properties presented in Andrews et al. (2011) for other mountaintop sites. All acronyms used in this work are reported in Table 1.

\section{Measurement site and methodology}

\subsection{Montsec measurement station}

The MSC site $\left(42^{\circ} 3^{\prime} \mathrm{N}, 0^{\circ} 44^{\prime} \mathrm{E}, 1570 \mathrm{~m}\right.$ a.s.l. $)$ is a highaltitude emplacement located in the NE of the Iberian Peninsula (Fig. 1) and situated in the southern side of the PrePyrenees at the top of Montsec d'Ares. This region is lowdensity populated and isolated from large pollutant emissions, $140 \mathrm{~km}$ from the highly urbanized and industrialized coastline to the southeast, $30 \mathrm{~km}$ from the largest city in the 
Table 1. Acronyms used in this work.

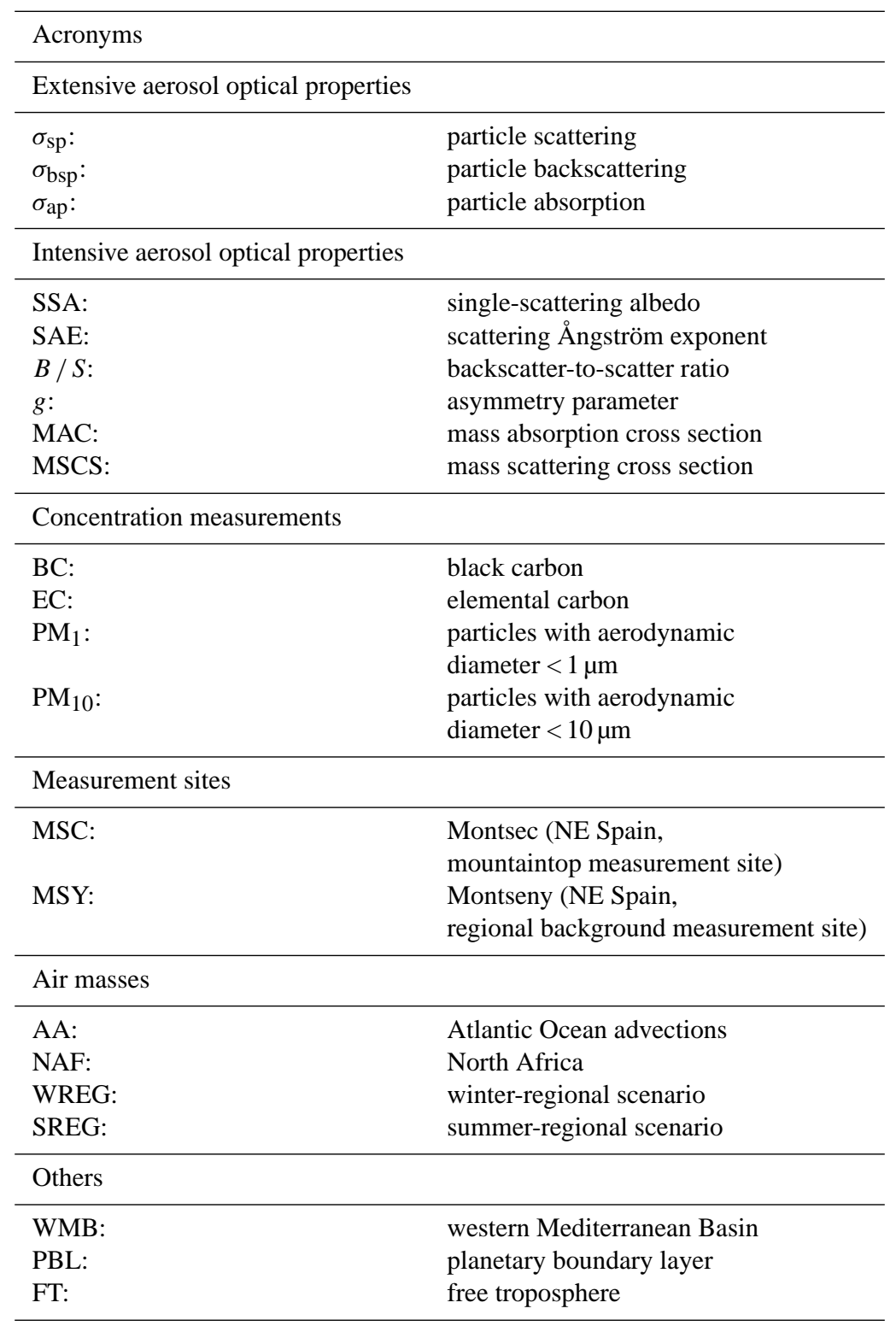

region (Balaguer, 15769 inhabitants) to the south, and $50 \mathrm{~km}$ from the axial Pyrenees to the north. The ACTRIS regional background station of MSY is located around $140 \mathrm{~km}$ from the MSC site. Figure 1 also shows three meteorological stations: Montsec Observatory ( $800 \mathrm{~m})$, Os de Balaguer (576 m) and Vallfogona de Balaguer (238 m).

Aerosol measurements presented in this work were performed at MSC during the period June 2011-June 2013. Due to the deployment of the nephelometer in measurement campaigns at other locations, scattering and backscattering data were not available from February 2012 to June 2012. Results from the MSC site were compared with those simultaneously obtained at the MSY station (Fig. 1). A description of the
MSY site and the optical measurement performed at MSY can be found in Pandolfi et al. (2011).

\subsection{Optical measurements}

\subsubsection{Scattering, hemispheric backscattering and absorption}

Particle scattering $\left(\sigma_{\mathrm{sp}}: 10-171^{\circ}\right)$ and hemispheric backscattering $\left(\sigma_{\mathrm{bsp}}: 90-171^{\circ}\right)$ coefficients at three wavelengths $(450 \mathrm{~nm}, 525 \mathrm{~nm}, 635 \mathrm{~nm})$ were measured with an LEDbased integrating nephelometer (model Aurora 3000, ECOTECH Pty Ltd, Knoxfield, Australia). The $\sigma_{\text {sp }}$ and $\sigma_{\text {bsp }}$ data were corrected for truncation errors, allowing scattering 


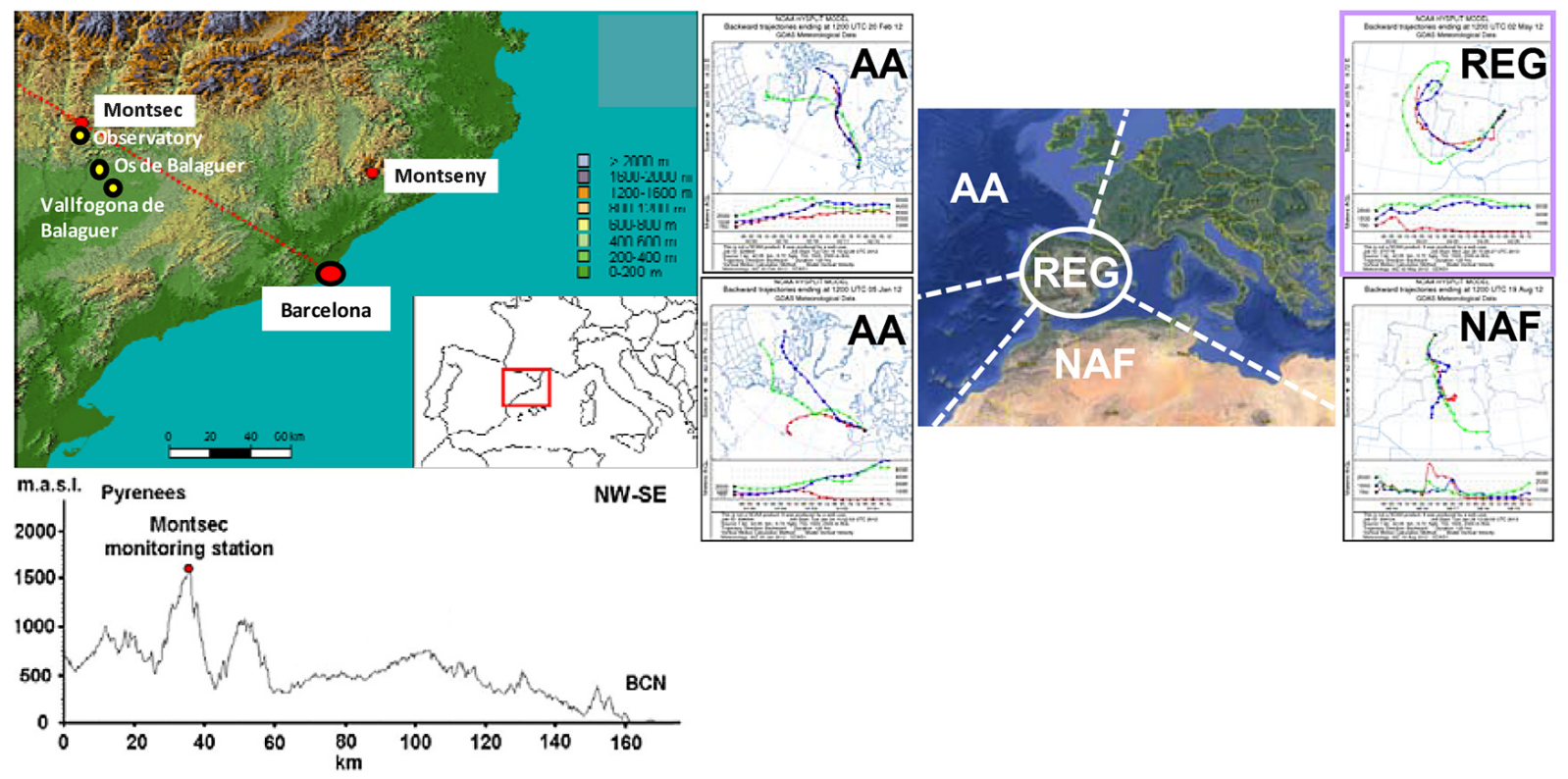

Figure 1. Location of the Montsec (MSC, remote mountaintop site) and Montseny (MSY, regional background) measurement sites. Barcelona is also shown. Yellow dots are meteorological stations (observatory ( $800 \mathrm{~m}$ a.s.1.), Os de Balaguer (576 m) and Vallfogona de Balaguer $(238 \mathrm{~m})$ ). Air mass back trajectories from the Atlantic Ocean (AA), regional (REG) and North Africa (NAF).

for $0-360^{\circ}$ and backscattering for $90-270^{\circ}$ to be reported, and for non-ideal (non-Lambertian) illumination function of the light source as described by Müller et al. (2011a). Müller et al. (2011a) provided parameterized correction factors for each wavelength as linear relationship of the Ångström exponents calculated from uncorrected multi-wavelength scattering measurements. A full calibration of the nephelometer was performed four times per year by using $\mathrm{CO}_{2}$ as span gas, while zero measurements and adjusts were performed once per week by using internally filtered particle free air.

In order to reduce the effects of hygroscopicity enhancing the scattering properties of particles, a relative humidity $(\mathrm{RH})$ threshold of $40 \%$ was set in the sampling cell by using a processor-controlled automatic heater inside the nephelometer. This experimental procedure, which follows the ACTRIS standards, has been applied elsewhere (see, for example, Pereira et al., 2011; Anderson and Ogren, 1998; Pandolfi et al., 2011). The mean RH in the nephelometer sampling cell during the study period was $28.4 \pm 9.5 \%$. Moreover, incloud data were removed by selecting only those data with ambient $\mathrm{RH}<90 \%$. The detection limits of Aurora 3000 over $1 \mathrm{~min}$ averaging time are $0.11,0.14$ and $0.12 \mathrm{Mm}^{-1}$ for total scattering at 450,525 and $635 \mathrm{~nm}$, respectively, and $0.12,0.11$ and $0.13 \mathrm{Mm}^{-1}$ for backscattering (Müller et al., 2011a).

Aerosol absorption coefficients $\left(\sigma_{\mathrm{ap}}\right)$ at $637 \mathrm{~nm}$ (Müller et al., 2011b) were measured with multi-angle absorption photometers (MAAP, model 5012, Thermo). The detection limit of the MAAP instrument is lower than $0.6 \mathrm{Mm}^{-1}$ over $2 \mathrm{~min}$ integration. Absorption measurements are converted by the
MAAP's software to BC concentration (in $\mu \mathrm{g} \mathrm{m}^{-3}$ ) assuming a constant MAC of $6.6 \mathrm{~m}^{2} \mathrm{~g}^{-1}$ (Petzold et al., 2004).

The nephelometer and MAAP instruments were connected to two separate sampling lines with cut-off diameters of 2.5 and $10 \mu \mathrm{m}$, respectively, and placed at about $1.5 \mathrm{~m}$ above the roof of the cabin hosting the instruments. The inlets flow was $1 \mathrm{~m}^{3} \mathrm{~h}^{-1}$ and humidity control was performed by connecting a drier to the sampling inlet. The Reynolds number for the described inlets was around 1300 . The scattering, backscattering and absorption measurements reported in this work were adjusted to standard temperature and pressure (STP, $T_{\text {standard }}=273.15 \mathrm{~K}$ and $\left.P_{\text {standard }}=1013.25\right)$.

\subsection{PM measurements}

Real-time $\mathrm{PM}_{10}, \mathrm{PM}_{2.5}$ and $\mathrm{PM}_{1}$ mass concentrations were continuously measured, on an hourly base, by using a GRIMM optical counter (model 1107). Subsequently, the $\mathrm{PM}_{\mathrm{x}}$ concentrations were corrected with factors obtained by comparing the real-time and simultaneous in situ gravimetric measurements (Querol et al., 2008). $\mathrm{PM}_{\mathrm{x}}$ gravimetric measurements on a $24 \mathrm{~h}$ base were performed twice per week with high-volume (Hi-Vol) samplers (DIGITEL and MCV at $30 \mathrm{~m}^{3} \mathrm{~h}^{-1}$ ) with appropriate $\mathrm{PM}_{\mathrm{x}}$ cut-off inlets.

\subsection{EC measurements}

The sampled $24 \mathrm{~h}$ filters from Hi-Vol were analysed by means of a SUNSET OCEC analyser for the determination of elemental carbon (EC) concentrations. The EUSAAR 2 protocol (Cavalli et al., 2010) was used. In this 
work the uncertainties for the measured EC concentrations were calculated by adding half of the minimum measured EC concentration to the $7 \%$ of the concentrations $(\operatorname{Err}[E C]=\min [E C] / 2+0.07 \cdot[E C])$. With the EUSAAR 2 protocol the EC uncertainties have been estimated to be around 2-7\% (JRC report, 2009). The formula applied here gives higher uncertainty to low EC concentrations (e.g. Polissar et al., 1998).

\subsection{Data processing}

In this work the aerosol scattering, backscattering and absorption coefficients were integrated over $1 \mathrm{~h}$. Six additional parameters ( $B / S, g$, SSA, SAE, MSCS and MAC) were derived from the aerosol optical and mass concentration measurements. The $B / S$ parameter, which is the ratio between hemispherical backscatter and total scatter, is used here to estimate the $g$ of airborne particles used in radiative transfer calculations (Andrews et al., 2006). Values of $g$ can range from -1 for $180^{\circ}$ backwards scattering to +1 for complete forward scattering $\left(0^{\circ}\right)$, with a value of 0.7 commonly used in radiative transfer models (Ogren et al., 2006). Following Delene and Ogren (2002) and Andrews et al. (2006), $g$ was calculated for the three nephelometer wavelengths as follows:

$g=-7.14(B / S)^{3}+7.46(B / S)^{2}-3.96(B / S)+0.9893$.

The SSA indicates the relative amounts of radiation scattered and absorbed by particles. Thus, SSA is a parameter indicating the potential for aerosols for cooling or warming the atmosphere. It is defined as

$$
\mathrm{SSA}=\frac{\sigma_{\mathrm{sp}}}{\sigma_{\mathrm{sp}}+\sigma_{\mathrm{ap}}} .
$$

Non-absorbing particles such as sulfate have an SSA of 1 (cooling), while lower SSA values indicate the presence of more absorbing particles. BC particles have an SSA of about 0.2 (warming). In this work SSA was estimated to be $635 \mathrm{~nm}$, as the difference between absorption at $637 \mathrm{~nm}$ (MAAP wavelength) and $635 \mathrm{~nm}$ was assumed to be negligible.

The SAE $(450-635 \mathrm{~nm})$ was calculated from the multiwavelength nephelometer data as

$\mathrm{SAE}=-\frac{\log \left(\sigma_{\mathrm{sp}}^{\lambda_{1}} / \sigma_{\mathrm{sp}}^{\lambda_{2}}\right)}{\log \left(\lambda_{1} / \lambda_{2} .\right)}$

The SAE describes the $\lambda$ dependence of the particle scattering coefficient. An Ångström exponent of 4 represents the scattering from molecules (Rayleigh's regime). A large SAE (higher than 2) implies scattering dominated by submicron particles, while SAE values lower than 1 represent an aerosol distribution dominated by coarser particles (e.g. Schuster et al., 2006).
In order to eliminate issues with measurement noise during clean periods (e.g. when MSC was in the FT), the $B / S, g$, SSA and SAE parameters were calculated from hourly averaged scattering $(635 \mathrm{~nm})$, hemispheric backscattering $(635 \mathrm{~nm})$ and absorption above $0.4,0.4$ and $0.6 \mathrm{Mm}^{-1}$, respectively.

The MAC and MSCS are a measurement of the efficiency of the measured particles to absorb or scatter, respectively, light at a given wavelength and are expressed in $\mathrm{m}^{2} \mathrm{~g}^{-1}$. The MAC is the parameter used to convert absorption to concentration of absorbing particles (i.e. BC or EC), and vice versa, and was estimated from error-weighted linear fitting between $\sigma_{\text {ap }}$ from MAAP and EC concentrations from offline filter analysis. MAAP data were averaged over the filter sampling time. The MSCS is the parameter relating the measured scattering to the concentration of PM and was estimated at the three nephelometer wavelengths by averaging the ratios between $\sigma_{\mathrm{sp}}$ and $\mathrm{PM}_{2.5}$ after subtracting the EC mass from PM.

\subsection{Main meteorological patterns}

In order to determine and classify the atmospheric episodes affecting MSC, HYSPLIT (http://ready.arl.noaa. gov/HYSPLITtraj.php), BSC/DREAM8b (http://www.bsc. es/projects/earthscience/DREAM), SKIRON (http://forecast. uoa.gr/dustindx.php) and NAAPS (http://www.nrlmry.navy. mil/aerosol) models were used. For each day of measurements, $120 \mathrm{~h}$ backward trajectories (for 12:00 modelling vertical velocity and for three different heights, 750, 1500 and $2500 \mathrm{~m}$ a.g.l) were computed and classified according to their predominant transport direction in the (1) Atlantic Ocean (AA, Atlantic north and Atlantic northwest; $52 \%$ ), (2) North Africa (NAF, $14 \%$ ), (3) winter regional (WREG, from November to April; 6\%), and (4) summer regional (SREG, from May to October; $9 \%$ ). The global atmospheric circulation has some seasonal oscillations, and thus MSC is more westerly and northerly influenced in winter, while in summer the prevailing winds come from the south (Ripoll et al., 2014). Consequently, AA episodes are more frequent in winter, whereas continental NAF air masses are more frequent in summer (Pandolfi et al., 2014, 2011; Querol et al., 2009; Pey et al., 2009; Pérez et al., 2008; Rodríguez et al., 2001). The advection of clean Atlantic air masses clears out the previously accumulated pollution in the aged air masses, leading to lower pollutant concentrations. In summer the meteorology of the area is mainly characterized by long dry periods, sporadic but occasionally heavy rains, and a prevalence of NAF outbreaks (Rodriguez et al., 2004). The WREG and SREG scenarios represent mainly air masses from the Iberian Peninsula (IP) (Rodriguez et al., 2004). In winter (WREG) recurrent anticyclonic conditions with weak synoptic winds lead to stagnation of air masses and the accumulation and aging of pollutants over the region. Under these conditions the PBL height mostly determines the dilution of pollutants around the emission sources and the degree of pollution at 
more elevated/regional areas in the WMB (e.g. Jorba et al., 2013; Pandolfi et al., 2014). In summer, due to the intense and rapid solar heating of the lower atmospheric layers, convergence of surface winds from the coast to the central IP plateau injects polluted air into the middle troposphere up to 3.5-5 km (Millán et al., 1997; Pérez et al., 2004). This pattern allows for the recirculation and accumulation of aerosol and has the potential to form stratified reservoir layers of aged pollutants which subside over the coastal area and the sea (e.g. Millán et al., 1992, Gangoiti et al., 2001; Pérez et al., 2004).

\section{Results and discussion}

\subsection{General features}

Table 2 reports the statistics for the measured parameters, including means, standard deviations, percentiles $(1,10,25$, $50,75,99$ percentiles), minima and maxima values and skewness. With the exception of SAE, MSCS and MAC, all parameters showed skewness higher than 1 , for which almost normal distributions (skewness close to zero) were observed, and SSA and $g$ both showing a negative skewness. Similar SSA skewness was presented by Pandolfi et al. (2011) at the MSY regional background measurement site. Negative skewness for $g$ is a consequence of the high positive skewness observed for $B / S$.

Hourly $\sigma_{\mathrm{sp}}$ and $\sigma_{\mathrm{bsp}}$ at $635 \mathrm{~nm}$ at MSC ranged between 0.1 and $161.1 \mathrm{Mm}^{-1}$ (mean \pm SD: $18.9 \pm 20.8 \mathrm{Mm}^{-1}$ ) and between 0.0 and $17.1 \mathrm{Mm}^{-1}\left(2.6 \pm 2.8 \mathrm{Mm}^{-1}\right)$, respectively. Mean values of $\sigma_{\mathrm{sp}}$ and $\sigma_{\mathrm{bsp}}$ at $450 \mathrm{~nm}$ and $525 \mathrm{~nm}$ are reported in Table 2. The $\sigma_{\text {ap }}$ (at $637 \mathrm{~nm}$ ) ranged between about 0.0 and $12.6 \mathrm{Mm}^{-1}$, with a mean value of $1.5 \pm 1.4 \mathrm{Mm}^{-1}$. The hourly $\mathrm{PM}_{1}$ levels at MSC ranged between about 0.1 and $49.9 \mu \mathrm{g} \mathrm{m}^{-3}$, with a mean value of $5.3 \pm 4.5 \mu \mathrm{g} \mathrm{m}^{-3}$.

As shown later the lowest scattering, backscattering and absorption at MSC were measured under AA and WREG episodes typically observed during the cold season in the WMB. Conversely, high $\sigma_{\mathrm{sp}}, \sigma_{\mathrm{bsp}}$ and $\sigma_{\mathrm{ap}}$ were measured during NAF and SREG episodes, which predominate in spring/summer.

A comparison between measurements performed at MSC with those reported for other high-altitude sites is reported in the following of this section and in the next sections. It should be taken into account that in some cases the comparison may be affected by the different size cut-off of the particles sampled at the different sites. At the Jungfraujoch high-alpine site ( $3580 \mathrm{~m}$ a.s.l., whole air sampled), FierzSchmidhauser et al. (2010) reported mean $\sigma_{\mathrm{sp}}$ at $550 \mathrm{~nm}$ of about $12 \mathrm{Mm}^{-1}$, by excluding NAF episodes, and around $20 \mathrm{Mm}^{-1}$, considering only the NAF episodes. At Izaña (Canary Islands, $\sim 2400 \mathrm{~km}$ a.s.l.; $\mathrm{PM}_{10}$ size cut-off) mean $\sigma_{\mathrm{sp}}$ and $\sigma_{\mathrm{ap}}$ at $550 \mathrm{~nm}$ of about $10 \mathrm{Mm}^{-1}$ and $0.8 \mathrm{Mm}^{-1}$, respectively, have been measured (Andrews et al., 2011). Monte
Cimone (Italy, $\sim 2200 \mathrm{~m}$ a.s.l.; whole air sampled) registered mean $\sigma_{\mathrm{sp}}$ and $\sigma_{\mathrm{ap}}$ of around 11 and $3 \mathrm{Mm}^{-1}$, respectively, and both parameters increased highly during Saharan dust outbreaks and wildfire emissions over North Africa (Andrews et al., 2011; Cristofanelli et al., 2009). The mean scattering and absorption values measured at MSC were lower than the values reported by Pandolfi et al. (2011) for the MSY regional background station ( $720 \mathrm{~m}$ a.s.l., $\mathrm{PM}_{10}$ size cut-off). Mean $\sigma_{\mathrm{sp}}(635 \mathrm{~nm})$ and $\sigma_{\mathrm{ap}}(637 \mathrm{~nm})$ at MSY were around 26.6 and $2.8 \mathrm{Mm}^{-1}$, respectively, due to the higher influence of anthropogenic emissions in the lower boundary layer (MSY) compared with higher altitudes (MSC).

The mean $B / S(525 \mathrm{~nm})$, SAE $(450-635 \mathrm{~nm})$, SSA $(635 \mathrm{~nm})$ and $g(525)$ measured at MSC were $0.135 \pm 0.066$, $1.56 \pm 0.88,0.92 \pm 0.03$ and $0.59 \pm 0.13$, respectively. At the alpine Jungfraujoch site, Fierz-Schmidhauser et al. (2010) reported mean $B / S$, SAE and SSA for dry aerosols $(\mathrm{RH}<20 \%)$ within the ranges $0.128-0.122,1.787-1.671$ and $0.91-0.93$, respectively. The higher $B / S$ measured at MSC was likely due to the lower size range measured at MSC $\left(\mathrm{PM}_{2.5}\right)$ compared with Jungfraujoch (whole air), whereas the lower SAE at MSC, despite the different size cut-off, may be an indication of the prevalence of slightly coarser aerosols at MSC. This difference was likely due to the fact that more large particles had time to deposit out or be removed via wet scavenging since the altitude of Jungfraujoch is about twice that of the MSC altitude.

At the MSY regional background station the mean $B / S$ $(525 \mathrm{~nm}), \operatorname{SAE}(450-635 \mathrm{~nm}), \operatorname{SSA}(635 \mathrm{~nm})$ and $g(525 \mathrm{~nm})$ were different by around $-16,+5,-4$ and $+6 \%$, respectively, compared to MSC (only contemporary data were used). These differences were small suggesting, on average, similarity in microphysical aerosol properties measured at the MSC and MSY stations. Recently, Ripoll et al. (2014) have shown that the mean chemical composition of particles at MSC and MSY is on average similar, mainly due to the frequency of specific meteorological episodes affecting aerosol properties similarly at both sites. The main difference was observed for $B / S$, which was higher at MSC, likely because of the lower size cut-off at MSC $\left(\mathrm{PM}_{2.5}\right)$ compared to MSY $\left(\mathrm{PM}_{10}\right)$. Moreover, the relatively lower SSA and higher SAE at MSY, despite the differences in the size cut-off, suggested the presence of relatively smaller and more absorbing particles at regional level, likely because the proximity of the MSY station to anthropogenic sources.

The mean MAC $\left( \pm\right.$ SD) at MSC was around $11 \pm 4 \mathrm{~m}^{2} \mathrm{~g}^{-1}$ and ranged from 2.4 to $20.8 \mathrm{~m}^{2} \mathrm{~g}^{-1}$. Mean MSCS $( \pm \mathrm{SD})$ at 635,525 and $450 \mathrm{~nm}$ were $2.5 \pm 1.4,3.3 \pm 1.9$ and $4.2 \pm 2.4 \mathrm{~m}^{2} \mathrm{~g}^{-1}$, respectively. As shown later (Sect. 3.5) the MAC and MSCS at MSC showed a clear seasonal dependence. These two parameters can change as a function of aerosol composition and age, and therefore it can differ depending on the area under study and the meteorological scenarios. MACs between 7 and $20 \mathrm{~m}^{2} \mathrm{~g}^{-1}$ have often been reported in the literature (e.g. Quinn and Bates, 2005; Bond and 
Table 2. Statistics of the considered aerosol components and parameters for the period June 2011-June 2013 at Montsec site (all data). The wavelength $(\lambda)$ is given in $[\mathrm{nm}]$; scattering $\left(\sigma_{\mathrm{sp}}\right)$, backscattering $\left(\sigma_{\mathrm{bsp}}\right)$ and absorption coefficients $\left(\sigma_{\mathrm{ap}}\right)$ are given in $\left[\mathrm{Mm}^{-1}\right]$; backscatteringto-scattering ratio $(B / S)$, asymmetry parameter $(g)$, single-scattering albedo (SSA) and the Ångström exponent (SAE) are dimensionless; $\mathrm{PM}_{1}$ concentrations are given in $\left[\mu \mathrm{g} \mathrm{m}^{-3}\right]$; and MAC and MSCS is expressed in $\left[\mathrm{m}^{2} \mathrm{~g}^{-1}\right]$. Statistics based on hourly mean values $(24 \mathrm{~h}$ for MAC and MSCS $)$. Optical data were referenced to STP $\left(T_{\text {standard }}=273.15 \mathrm{~K}\right.$ and $\left.P_{\text {standard }}=1013.25 \mathrm{hPa}\right)$.

\begin{tabular}{|c|c|c|c|c|c|c|c|c|c|c|c|c|c|}
\hline \multirow[t]{2}{*}{ Hourly base } & \multirow[t]{2}{*}{$\lambda$} & \multirow[t]{2}{*}{ Counts } & \multirow[t]{2}{*}{ Mean } & \multirow[t]{2}{*}{ SD } & \multirow{2}{*}{$\begin{array}{r}\text { Median } \\
\text { (50th perc.) }\end{array}$} & \multirow[t]{2}{*}{ Min } & \multirow[t]{2}{*}{ Max } & \multirow[t]{2}{*}{ Skewness } & \multicolumn{5}{|c|}{ Percentiles } \\
\hline & & & & & & & & & 1 & 10 & 25 & 75 & 99 \\
\hline \multirow{3}{*}{$\sigma_{\mathrm{sp}}$} & 635 & 10014 & 18.9 & 20.8 & 11.2 & 0.1 & 161.1 & 1.83 & 0.2 & 1.1 & 3.5 & 28.3 & 89.8 \\
\hline & 525 & 10014 & 25.4 & 27.5 & 15.1 & 0.1 & 222.2 & 1.68 & 0.1 & 1.6 & 4.5 & 38.6 & 118.5 \\
\hline & 450 & 10014 & 32.3 & 34.7 & 19.3 & 0.1 & 276.2 & 1.62 & 0.1 & 2.0 & 5.6 & 49.6 & 143.6 \\
\hline \multirow[t]{3}{*}{$\sigma_{\mathrm{bsp}}$} & 635 & 10014 & 2.6 & 2.8 & 1.7 & 0.0 & 17.1 & 1.25 & 0.1 & 0.2 & 0.4 & 4.3 & 11.1 \\
\hline & 525 & 10014 & 3.1 & 3.2 & 1.9 & 0.0 & 36.4 & 1.31 & 0.1 & 0.2 & 0.5 & 5.1 & 12.8 \\
\hline & 450 & 10014 & 3.6 & 3.9 & 2.2 & 0.0 & 96.0 & 1.21 & 0.1 & 0.2 & 0.5 & 6.0 & 14.6 \\
\hline \multirow[t]{3}{*}{$B / S$} & 635 & 8612 & 0.16 & 0.09 & 0.15 & 0.02 & 0.99 & 4.03 & 0.04 & 0.10 & 0.12 & 0.18 & 0.58 \\
\hline & 525 & 8864 & 0.13 & 0.07 & 0.13 & 0.01 & 0.98 & 4.78 & 0.04 & 0.09 & 0.11 & 0.15 & 0.44 \\
\hline & 450 & 8761 & 0.12 & 0.06 & 0.11 & 0.01 & 1.00 & 4.95 & 0.03 & 0.07 & 0.10 & 0.13 & 0.36 \\
\hline$\sigma_{\mathrm{ap}}$ & 637 & 13712 & 1.5 & 1.4 & 1.0 & 0.0 & 12.6 & 1.45 & 0.0 & 0.1 & 0.3 & 2.4 & 6.2 \\
\hline \multirow[t]{3}{*}{$g$} & 635 & 8587 & 0.53 & 0.16 & 0.54 & -0.99 & 0.93 & -2.51 & -0.10 & 0.39 & 0.49 & 0.60 & 0.85 \\
\hline & 525 & 8858 & 0.59 & 0.13 & 0.59 & -0.92 & 0.94 & -3.25 & 0.09 & 0.49 & 0.55 & 0.64 & 0.85 \\
\hline & 450 & 8755 & 0.62 & 0.11 & 0.62 & -0.79 & 0.95 & -2.15 & 0.20 & 0.53 & 0.58 & 0.66 & 0.88 \\
\hline SAE & $450-635$ & 9561 & 1.56 & 0.88 & 1.65 & -1.96 & 5.99 & 0.30 & -1.14 & 0.56 & 1.22 & 1.90 & 4.69 \\
\hline SSA & 635 & 6123 & 0.92 & 0.03 & 0.93 & 0.45 & 0.99 & -2.59 & 0.81 & 0.89 & 0.91 & 0.94 & 0.97 \\
\hline MAC & 637 & 384 & 10.9 & 3.5 & 11.1 & 2.4 & 20.8 & 0.21 & 3.6 & 6.2 & 8.2 & 13.2 & 19.8 \\
\hline \multirow[t]{3}{*}{ MSCS } & 635 & 228 & 2.5 & 1.4 & 2.4 & 0.1 & 7.5 & 0.66 & 0.2 & 0.7 & 1.3 & 3.4 & 6.8 \\
\hline & 525 & 228 & 3.3 & 1.9 & 3.2 & 0.1 & 10.3 & 0.74 & 0.2 & 1.1 & 1.8 & 4.6 & 9.3 \\
\hline & 450 & 228 & 4.2 & 2.4 & 4.0 & 0.2 & 12.9 & 0.73 & 0.3 & 1.5 & 2.2 & 5.9 & 11.8 \\
\hline $\mathrm{PM}_{1}$ & - & 10949 & 5.3 & 4.5 & 4.0 & 0.1 & 49.9 & 2.06 & 0.5 & 1.4 & 1.9 & 7.2 & 21.8 \\
\hline
\end{tabular}

Bergstrom, 2006; Fernandez-Camacho et al., 2010; Arnott et al., 2003, 2005; Reche et al., 2011; Pandolfi et al., 2011; Querol et al., 2013).

\subsection{Diurnal cycles and cluster analysis}

As shown in Fig. 2 the mean scattering and absorption at MSC exhibited diurnal cycles with lower values at night and higher values in the afternoon. Thus, on average, thermally driven upslope winds and PBL height variations favoured the transport of pollutants toward the MSC site during the warmest hours of the day. Similar diurnal variations at other mountaintop sites have been observed for extensive aerosol optical properties (e.g. Andrews et al., 2011) and physical properties (e.g. Venzac et al., 2009; Marinoni et al., 2008). The absolute values of extensive optical properties and PM mass concentrations and their diurnal cycle amplitudes were higher at the MSY site compared to MSC (Fig. 2), mainly because the proximity of MSY to the highly urbanized/industrialized coastline (Fig. 1) and its lower altitude compared to MSC. As a consequence, the SSA and SAE at the MSY station also showed marked diurnal cycles com- pared to MSC due to the effectiveness of thermally driven upslope winds in transporting fine highly absorbing particles of anthropogenic origin to MSY (Fig. 2; cf. Pandolfi et al., 2014).

The $\sigma_{\mathrm{sp}}$ and $\sigma_{\text {ap }}$ measured at MSC showed marked differences as a function of the different synoptic scenarios, with the lowest values measured under AA and WREG and the highest measured under NAF and SREG (Fig. 2). The mean scattering at MSC under NAF and SREG scenarios was close to the values measured at the MSY regional background station, whereas lower scattering was measured at MSC under AA and WREG compared to MSY. A similar pattern was observed for fine $\mathrm{PM}_{1}$ concentrations (Fig. 2). The similarities in $\sigma_{\mathrm{sp}}$ at MSC and MSY under NAF and SREG demonstrate the potential of these two summer atmospheric scenarios in polluting both regional and remote areas in the WMB. The potential of SREG scenarios to produce atmospheric reservoir layers of aged pollutants is also demonstrated by the similarity in the concentrations of fine PM at both sites despite their different altitude and distance from important pollution sources. Conversely, mean $\sigma_{\mathrm{sp}}$ and 


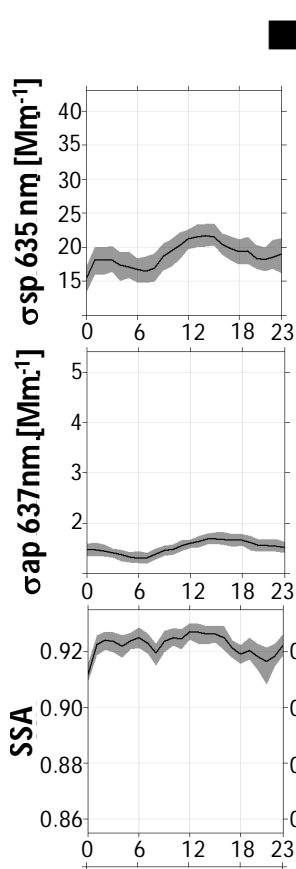

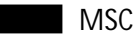
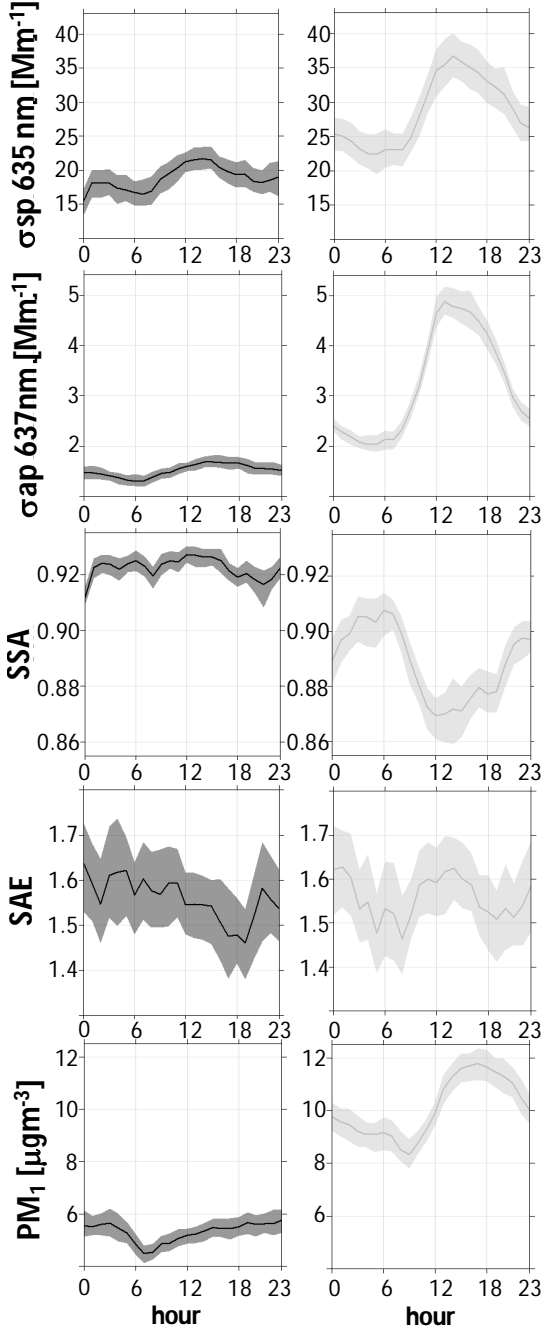

MSY

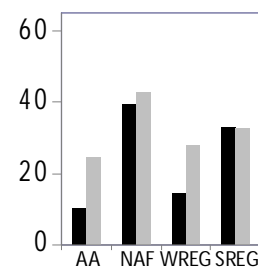

4
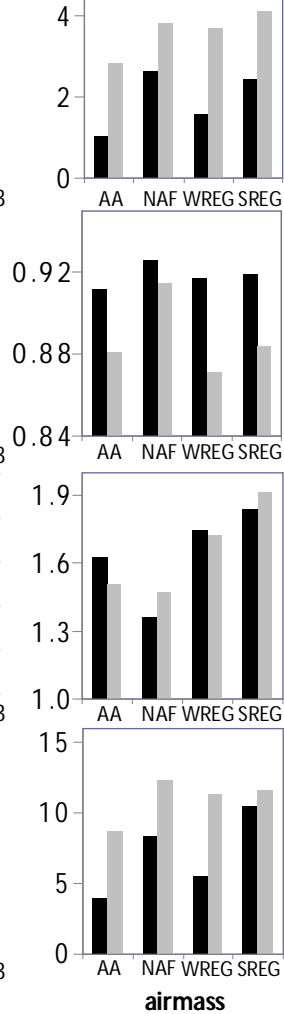

Figure 2. Diurnal cycles and cluster analysis of scattering $\left(\sigma_{\mathrm{sp}}\right.$ at $635 \mathrm{~nm})$, absorption $\left(\sigma_{\text {ap }}\right.$ at $\left.637 \mathrm{~nm}\right)$, single-scattering albedo (SSA at $635 \mathrm{~nm}$ ), scattering Ångström exponent (SAE calculated between 450 and $635 \mathrm{~nm}$ ) and $\mathrm{PM}_{1}$ concentrations measured at Montsec site (MSC, black lines) and at Montseny regional background site (MSY, grey lines). Atmospheric scenarios are Atlantic advection (AA), African dust outbreaks (NAF), winter regional anticyclonic episodes (WREG) and summer regional recirculation episodes (SREG).

$\mathrm{PM}_{1}$ concentrations at MSC under WREG were relatively lower compared to MSY despite the general winter anticyclonic conditions in the WMB, which favour the accumulation of pollutants around the emission sources. However, as already stated, the degree of pollution at rural/remote elevated areas under WREG strongly depends on PBL height. We will show later that MSC was predominantly in the free troposphere in winter when WREG scenarios were observed. Conversely, during WREG the height of the polluted PBL can often reach the altitude of MSY (Pandolfi et al., 2014).
The absorption measured at MSC was lower compared with MSY for all considered scenarios due to the proximity of the MSY station to anthropogenic sources of BC compared to MSC. As a consequence, the SSA was higher at MSC than at MSY irrespective of the atmospheric scenarios. The highest SSA at both sites was measured under NAF scenarios due to the higher relative concentrations of dust particles from Africa enhancing the scattering. Finally, the SAE showed similar characteristics at the two sites with lower values observed under NAF (due to the transport of coarser particles) and higher values under SREG (due to the increased relative concentration in the atmosphere of fine ( $\left.\mathrm{PM}_{1}\right)$ particles of anthropogenic origin).

\subsection{FT conditions at MSC station}

\subsubsection{Identification of FT air}

For the identification of FT air we followed the definition given by Andrews et al. (2011, AND2011 from now on) based on the use of data collected between 03:00 and 09:00 LT. As reported in AND2011, this criterion appears to be reasonable for most mountaintop sites and seasons. The limitations of this "time of day" approach are related to the location, height and topography of the site, which determine the strength and frequency of local thermally driven flow and the presence/intensity of polluted residual layers. All these factors make it difficult to rigorously define FT air. In the WMB the frequent SREG and NAF episodes in spring/summer further complicate the identification of the FT air. In order to evaluate when the MSC station was in the FT, we used meteorological data collected at MSC and at three lower altitude meteorological stations (Fig. 1). Thus, contemporary meteorological data collected at MSC station (1570 m a.s.1.), Montsec Observatory $(800 \mathrm{~m})$, Os de Balaguer $(576 \mathrm{~m})$ and Vallfogona de Balaguer $(238 \mathrm{~m})$ were used to study the mean diurnal cycles of potential temperature (Fig. 3a), relative humidity (Fig. 3b) and water vapour mixing ratio (Fig. 3c) as a function of altitude. The potential temperature and water vapour mixing ratio were calculated with the humidity conversion formulas provided by Vaisala (Vaisala Oyj, 2013). Moreover, the diurnal cycles of the gradients of potential temperature (Fig. 3e) and actual temperature (Fig. 3f) were also reported in order to study the strength of the nocturnal and diurnal thermal inversions between the four sites (i.e. between mountain and valley). This analysis may be affected by differences due to different instruments, calibration procedures or local features associated with a specific location (the MSC station and Vallfogona de Balaguer were around $35 \mathrm{~km}$ apart). Consequently, we also simulated the mean seasonal PBL diurnal cycles at MSC (Fig. 3d) by means of the HYSPLIT model (http://www.ready.noaa.gov/ READYamet.php). Grey and yellow rectangles in Fig. 3 respectively highlight hours when the MSC station was within the PBL and the hours of the time of the day approach (from 
03:00 to 09:00 LT) for the identification of FT air proposed by Andrews et al. (2011). In this analysis we assumed that, in a well-mixed mixing layer, the water vapour mixing ratio and potential temperature should be nearly constant with altitude within the PBL. In the free troposphere the water vapour content and potential temperature will decrease and increase, respectively, with altitude. Moreover, if the mixing layer has a uniform distribution of water vapour throughout, then the relative humidity has to increase with altitude. Figure 3 shows that when the relative humidity at MSC was higher compared to the other three stations, the potential temperature and water vapour content were fairly similar. We used these conditions to define the PBL air (grey rectangles). Conversely, at night/in the early morning (yellow rectangles) the relative humidity at MSC was the lowest and the differences in potential temperature and water vapour content among the four stations were the highest. Moreover, the gradients of potential temperature and actual temperature show that strong inversions were on average observed at night between Montsec Observatory and Os de Balaguer with MSC station above the inversion. Conversely, the gradients were lower and rather similar when MSC was within the PBL (grey rectangles). Figure 3 also shows that our estimation of PBL conditions obtained using meteorological data agrees satisfactorily with the simulation performed with HYSPLIT.

Thus, the MSC station was on average above the inversion at night-early morning and within the PBL during the warmest hours of the day in summer, spring and autumn. Thus, the presence of polluted PBL residual layers at MSC altitude at night cannot be excluded. Conversely, in winter the MSC was on average in the FT during the whole day.

Figure 4 shows that the highest diurnal cycle amplitude of scattering at MSC was observed in winter, whereas in spring and summer no clear diurnal cycles were observed. The remarkable diurnal cycle of aerosol scattering in winter was due to the position of MSC station in the free troposphere, whereas thermally driven flows can transport pollutants toward MSC around midday. The observed reduced diurnal cycle for scattering at MSC during spring and summer was mainly due to the frequent occurrence of NAF and SREG episodes and to the possible presence of polluted residual layers at night at the MSC altitude. The NAF and SREG scenarios were also linked with high concentrations of PM and BC during the whole day by Ripoll et al. (2014). Thus, as already observed by Venzac et al. (2009) for the Puy de Dôme station, the seasonal change in FT data at MSC was in part due to the seasonal variability in air mass origin and transport routes.

\subsubsection{FT vs. all data: comparison with mountaintop sites presented in AND2011}

Figure 5 shows the median values for all periods (June 2011June 2013) and by season at MSC for the six aerosol optical parameters presented in AND2011. MSC data were scaled to a wavelength of $550 \mathrm{~nm}$ (used in AND2011) by using 1.6 as SAE (median values for MSC, this work) and 1.4 as the absorption Ångström exponent (AAE). The AAE was calculated from 1-month absorption measurements performed at MSC with a seven-wavelength Aethalometer (model AE33, Magee Scientific). For MSC the values were calculated for the whole period considered here (ALL, June 2011-June 2013), as well as for autumn (SON), winter (DJF), spring (MAM) and summer (JJA). Red and yellow colours in Fig. 5 represent all data (averaged over 24h) and FT data (averaged between 03:00 and 09:00LT), respectively. The percentage values in each figure represent the relative difference between the medians calculated for all data and FT data, with positive values indicating lower FT-data medians compared to all data. The non-parametric Mann-Whitney U test was applied to study whether the differences between all-data and FT-data medians were statistically significant. In Fig. 5, bold green numbers indicate statistically significant differences to a significance level of $5 \%$ ( $p$ value $<0.05$ ), blue bold numbers highlight marginally significant differences $(p<0.1)$, whereas black numbers report differences which were not statistically significant $(p>0.1)$. The six red and yellow rectangles within the blue areas on the right of each figure represent the range of variability of the medians presented by AND2011 calculated for mountaintop sites in the Western Hemisphere (W), Europe (EU) and the Eastern Hemisphere (E).

As reported in Fig. 5 the scattering (median $14.1 \mathrm{Mm}^{-1}$; Fig. 5a ALL, all data) and the absorption (1.2 $\mathrm{Mm}^{-1}$; Fig. $5 \mathrm{~b}$ ALL, all data) measured at MSC for the whole data set (ALL) locate the MSC site in the medium/upper range of EU ranges. This is especially marked for scattering data. As reported in Fig. 5 higher scattering and absorption at MSC were measured in summer (JJA, all data; $34.6 \mathrm{Mm}^{-1}$ and $2.4 \mathrm{Mm}^{-1}$, respectively) compared to winter (DJF, all data; $3.7 \mathrm{Mm}^{-1}$ and $0.3 \mathrm{Mm}^{-1}$, respectively). As already noted, the NAF and SREG episodes affecting the WMB have the potential to increase the aerosol mass and scattering measured in this area in summer (Fig. 2 and JJA scattering in Fig. 4). At the same time, the lower altitude of MSC station compared with the stations reported in AND2011 (lowest altitude around $2.2 \mathrm{~km}$ ) may have also contributed to the relatively higher scattering observed at MSC station. Recently, Ripoll et al. (2014) have shown that the MSC site registers higher $\mathrm{PM}_{10}$ concentrations than those measured at other high-altitude central European sites and similar or lower BC concentrations. As a consequence, the median value of SSA at MSC (0.93; Fig. 5d ALL, all data) was relatively higher compared with the EU, W and E ranges of variability. Conversely, SAE (1.65; Fig. 5e ALL, all data) and $B / S(0.126$; Fig. 5f ALL, all data) were in the middle of the corresponding EU ranges. The SSA at MSC did not change considerably as a function of seasons and varied between 0.92 (SON) and 0.94 (DJF). Conversely, SAE was higher in summer (1.74; Fig. 5e JJA, all data) compared to winter (1.39; Fig. 5e DJF, 

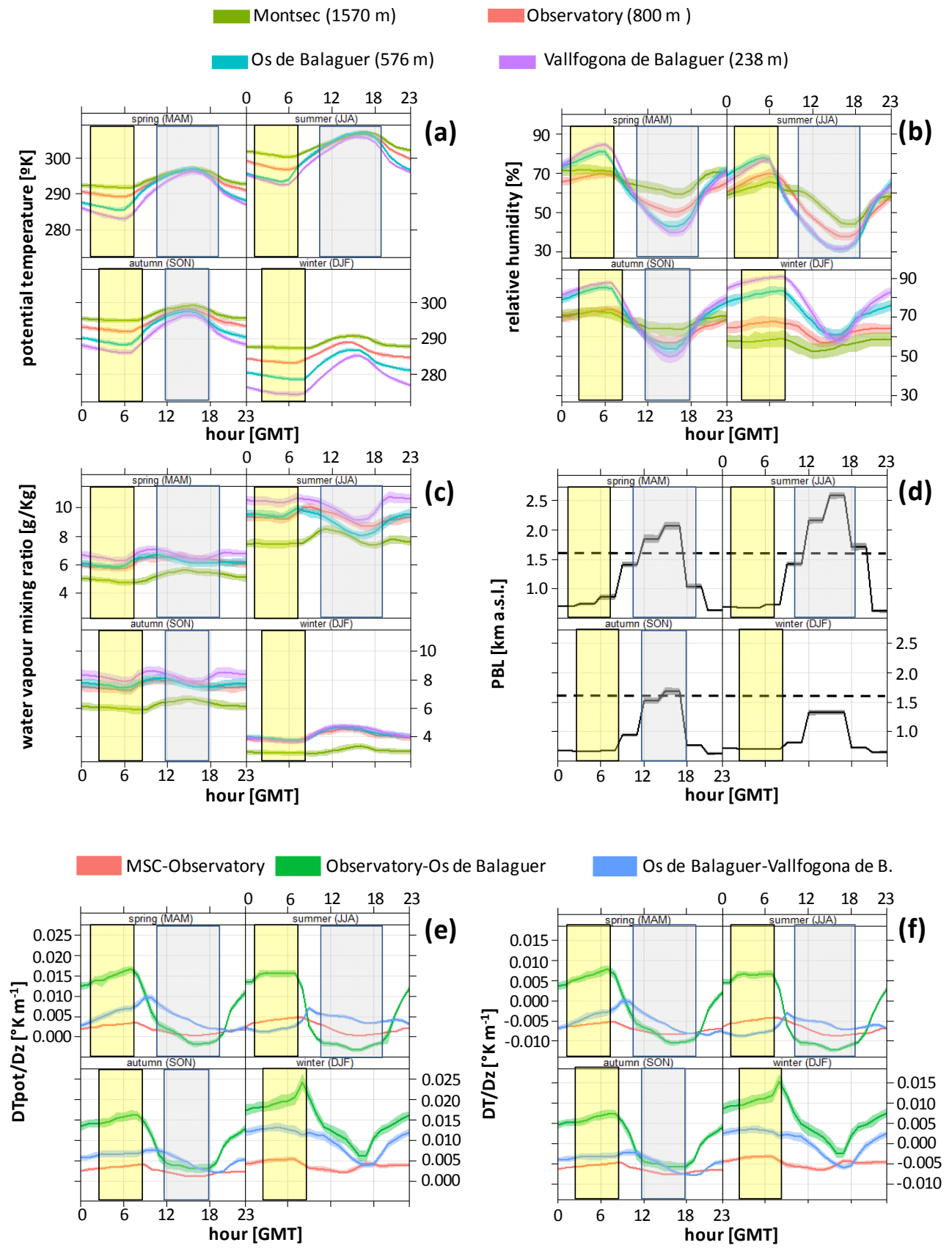

Figure 3. Seasonal diurnal cycles of relative humidity, potential temperature and water vapour mixing ratio measured at Montsec (1570 m a.s.1.), Montsec Observatory $(800 \mathrm{~m})$, Os de Balaguer $(576 \mathrm{~m})$ and Vallfogona de Balaguer $(238 \mathrm{~m})$. Also shown are the diurnal cycles of the planetary boundary layer height (PBL) from HYSPLIT and of the potential temperature and actual temperature gradients. Yellow rectangles highlight the time of the day approach for the identification of FT air proposed in Andrews et al. (2011) and used in this work (from 03:00 to 09:00 LT). Times are reported in GMT. Grey rectangles highlight hours when the MSC station was within the planetary boundary layer. Meteorological data at the four stations were available from 1 January 2011 to 31 December 2012.

all data). The relatively higher SAE observed in summer suggested the prevalence, on average, of finer particles at MSC compared to winter likely due to the frequent SREG scenarios observed during the warm season (cf. Fig. 2). Accordingly, the lowest $B / S$ was measured in winter $(0.119$; Fig. $5 \mathrm{f}$
DJF, all data) and the highest in summer (0.130; Fig. 5f JJA, all data).

All the extensive aerosol properties (scattering, absorption and extinction) showed relatively lower FT-data medians compared with all data (16-19\%; ALL in Fig. 5a, b, 


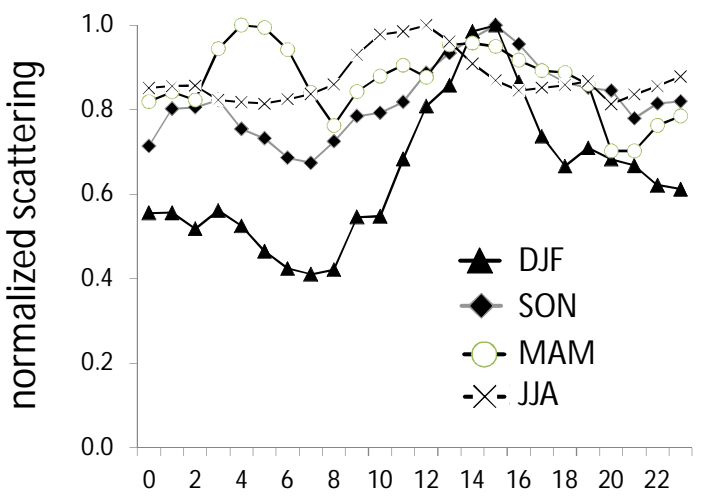

Figure 4. Diurnal cycles of normalized aerosol scattering at $550 \mathrm{~nm}$ measured at MSC as a function of the seasons: winter (DJF), autumn (SON), spring (MAM) and summer (JJA).

c). This was a common characteristic for most of the stations presented in AND2011. However, the relative decreases in FT-data extensive properties were clearly seasonal at the MSC site with the highest FT- vs. all-data difference observed in winter (DJF in Fig. 5a, b, c; 21-23\%) and the lowest in spring/summer (MAM and JJA in Fig. 5a, b, c; 0$8 \%$ ). The differences between the FT-data and all-data medians were statistically significant for ALL, SON and DJF and marginally significant for JJA. As a consequence of the time of day segregation used for the identification of FT air (03:00-09:00 vs. $24 \mathrm{~h}$ ) the remote sites showing stronger diurnal cycles tend to have larger decreases in FT aerosol loading compared to all-data (24h) aerosol loading (Andrews et al., 2011). In our case, the high FT- vs. all-data difference observed in winter is consistent with the strong DJF diurnal cycle of normalized scattering presented in Fig. 4.

The lower FT- vs. all-data difference in spring/summer was due to the occurrence of NAF and SREG episodes and to the fact that FT conditions were less frequent in spring/summer due to higher boundary layer. Finally, the differences between the FT-data and all-data medians calculated for the intensive aerosol properties were statistically significant only for SAE in winter (DJF) with slightly higher SAE observed for FT air (1.47; Fig.5e DJF, FT-data).

\subsection{Relationships between $\sigma_{\mathrm{sp}}$ and other extensive/intensive aerosol properties}

Figure 6 shows the relationships between $\sigma_{\mathrm{sp}}$ and some of the measured extensive (backscattering, absorption, $\mathrm{PM}_{1}$ concentrations) and intensive ( $g$, SAE, SSA) aerosol properties. Relationships are presented for the whole database (ALL, highlighted by the blue rectangle) and as a function of the main considered meteorological patterns (AA, NAF, SREG, WREG). Similar relationships were investigated, for example, by Delene and Ogren (2002), Pandolfi et al. (2011) and Andrews et al. (2011). However, to our knowledge, this is the first time that these relationships are presented as a function of air mass type. These kind of relationships helps to constrain model parameterizations and to reduce uncertainties in the algorithms used for deriving intensive aerosol properties from remotely sensed data (Delene and Ogren, 2002). In Fig. 6 the frequency distribution of scattering coefficient at $635 \mathrm{~nm}$ was calculated for values between 0 and $90 \mathrm{Mm}^{-1}$ with a bin of $5 \mathrm{Mm}^{-1}$ for ALL and NAF scenario. For AA, SREG and WREG scenarios the occurrence for high $\sigma_{\text {sp }}$ was lower, thus limiting the frequency distributions to 75,75 and $55 \mathrm{Mm}^{-1}$, respectively.

As shown in Fig. 6 the frequency distribution of aerosol scattering was more right-skewed during AA $(\mathrm{sk}=1.93)$ and WREG $(\mathrm{sk}=1.45)$ compared with NAF $(\mathrm{sk}=0.92)$ and SREG $(\mathrm{sk}=0.83)$ when pollution levels at MSC were higher (Fig. 2).

As reported in Fig. 6 the backscattering and $\mathrm{PM}_{1}$ concentrations increased with increasing $\sigma_{\mathrm{sp}}$. If the $\mathrm{PM}_{1}$ concentrations increase the intensity of light scattered, and also backscattered, increases almost monotonically. Also, the absorption, which is roughly proportional to the concentration of absorbing aerosols in PM samples, increased with increasing scattering and $\mathrm{PM}_{1}$ concentration. Similar findings were reported by Pandolfi et al. (2011) for the MSY site and by AND2011 (Fig. 6a in AND2011) for the 10 stations considered in their paper. AND2011 observed that the measurement sites which were dominated by dust aerosol at high aerosol loading tend to have a lower slope of the scattering-absorption relationship than the other sites. This is also the case at MSC, which shows a scattering-absorption slope in the lower range of those reported by AND2011 (cf. with Fig. 6a in AND2011). Figure 6 shows that the increase in the extensive aerosol properties with increasing aerosol scattering was fairly similar during the different considered meteorological scenarios, thus leading to very similar SSA as also reported in Fig. 2. Conversely, the most remarkable difference among the scenarios was observed for SAE, which decreased with increasing scattering during NAF reaching values around 0.8 at $\sigma_{\mathrm{sp}}=90 \mathrm{Mm}^{-1}$. Thus, the SAE was clearly a function of NAF intensity. Conversely, during SREG SAE was higher and nearly constant (around 1.8 for $0<\sigma_{\mathrm{sp}}<90 \mathrm{Mm}^{-1}$ ), indicating the prevalence of smaller particles with a relatively lower $g(0.53$ during SREG compared with 0.57 during NAF). No remarkable differences were observed for the intensive aerosol properties between the less polluted WREG and AA scenarios.

On average (ALL in Fig. 6) the parameters $g$ and SAE measured at MSC showed inverse relationships with $\sigma_{\mathrm{sp}}$ : when $\sigma_{\mathrm{sp}}$ increased above around $45-50 \mathrm{Mm}^{-1}$, SAE decreased, indicating the shift toward larger particles with relatively higher $g$ and SSA. The observed decrease of SAE was due to the prevalence of dust (i.e. large, primarily scattering) particles at high aerosol load at MSC.

To further investigate the effect of NAF episodes on SAE, in Fig. 7 we report the distribution of $\sigma_{\mathrm{sp}}$ as a function of SAE by means of atmospheric scenarios (Fig. 7a) and levels 

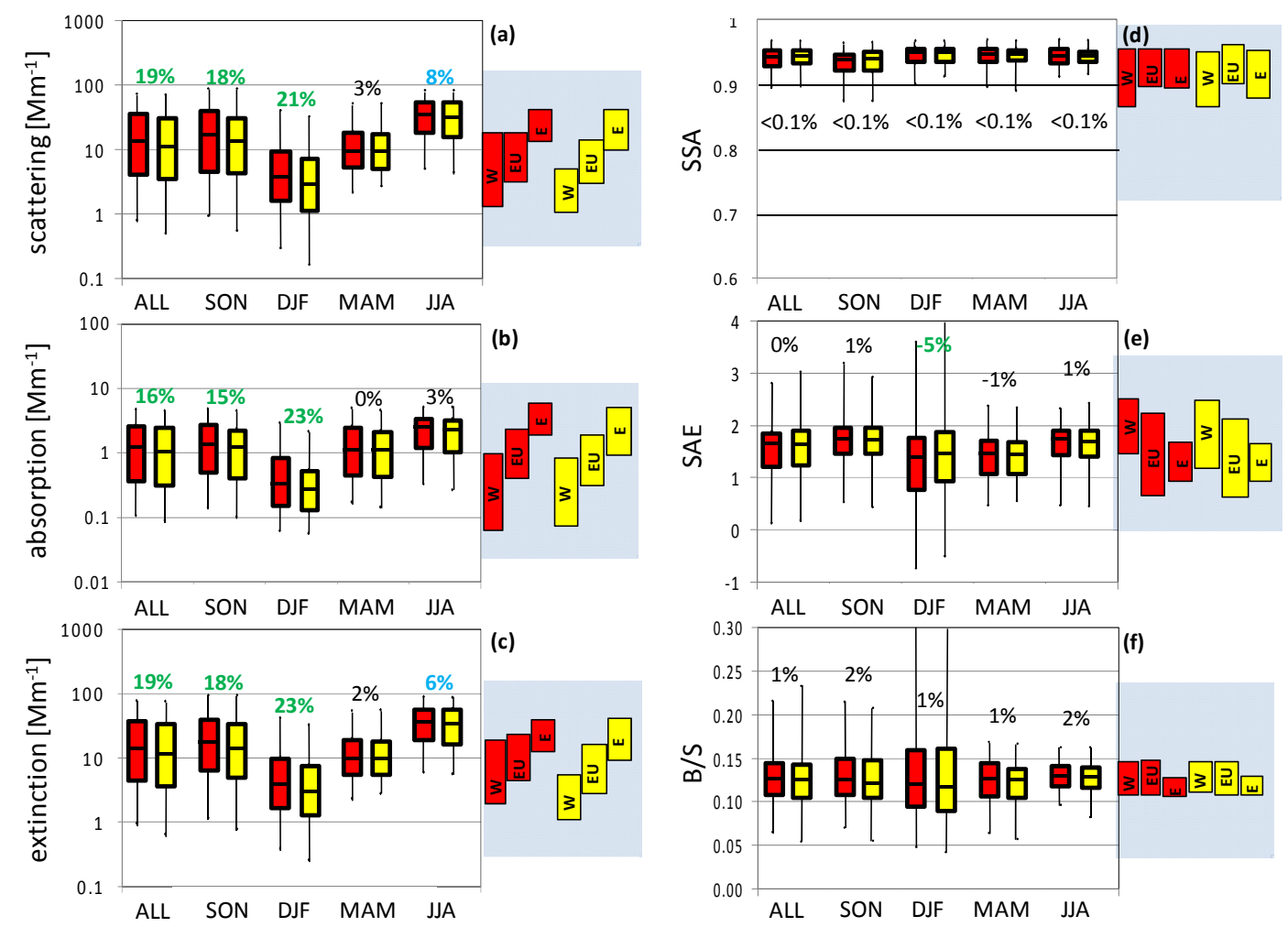

Figure 5. Aerosol optical properties for all data and FT data. Data are reported at $550 \mathrm{~nm}$. Red represents all data, and yellow represents FT data. Horizontal lines within the boxes are the medians (50th percentile), the bottom and top of each box are 25 th and 75 th percentiles, respectively, and whiskers are 5th and 95th percentiles. The Angström exponent is calculated for 450/635 nm pair. For MSC, values are calculated for the whole period considered here (ALL), and for autumn (SON), winter (DJF), spring (MAM) and summer (JJA). The percentage values represent the relative difference between the medians calculated for all data and FT data. Green bold numbers indicate statistically significant differences ( $p$ value $<0.05$ ); blue bold numbers highlight marginally significant differences $(p<0.1)$; black numbers indicate differences which were not statistically significant $(p>0.1)$. The red and yellow rectangles within the blue areas on the right of each figure represent the range of variability of the medians presented by Andrews et al. (2011) calculated for sites in the Western Hemisphere (W), Europe (EU) and the Eastern Hemisphere (E).

of $\mathrm{PM}_{1} / \mathrm{PM}_{10}$ ratio (Fig. 7b). As shown in Fig. 7a, high scattering and relatively low $\mathrm{SAE}(<1)$ were associated with $\mathrm{NAF}$ episodes (yellow). Correspondingly, the $\mathrm{PM}_{1} / \mathrm{PM}_{10}$ ratio was among the lowest $(0.2-0.3$, Fig. $7 b)$, indicating the prevalence of coarser particles. The AA scenarios (blue in Fig. 7a) were mainly associated with relatively lower scattering $\left(11.7 \pm 13.9 \mathrm{Mm}^{-1}\right.$ at $\left.635 \mathrm{~nm}\right)$, a broad range of SAE values (from -2 to 4 ) and $\mathrm{PM}_{1} / \mathrm{PM}_{10}$ ratios around $0.3-$ 0.5. Cermac et al. (2010) suggested that negative SAE could be an indication of reduced anthropogenic emissions with prevalence of coarse-mode particles. For example negative SAE and high aerosol optical depth (AOD) were related to transport of coarse-mode dust in northern India by Singh et al. (2004). However, extremely negative values of SAE are unfeasible for atmospheric aerosols. Similarly, the SAE cannot be higher than about 4, which represents the limit given by the Rayleigh regimen for the molecular scattering. In the present case 123 hourly values of SAE out of 9561 were smaller than $-1(1.2 \%)$ and 150 values were higher than 4
(1.6\%). Consequently, the measured negative SAE at MSC were likely due to both the presence of relatively larger particles during low aerosol concentration (Fig. 7b) and the instrumental noise under low scattering conditions. Similar behaviour of SAE was also observed in a remote subarctic site by Aaltonen et al. (2006) and at the MSY station by Pandolfi et al. (2011). Finally, the SREG episodes mainly (red, Fig. 7a), and to a lesser extent WREG (orange), were associated with relatively larger SAE compared with NAF and high $\mathrm{PM}_{1} / \mathrm{PM}_{10}$ ratios, indicative of the prevalence of mainly fine particles of anthropogenic origin.

For $\sigma_{\mathrm{sp}}$ between around 20 and $40 \mathrm{Mm}^{-1}$ (ALL in Fig. 6) both $g$ and SAE showed relatively constant values around $0.55(\mathrm{~g})$ and 1.65 (SAE), which were close to the averages reported in Table 2 for these two parameters. When $\sigma_{\mathrm{sp}}$ was below around $15-20 \mathrm{Mm}^{-1}$, SAE decreased, indicating again the shift toward relatively larger particles associated with relatively clean atmosphere $\left(\mathrm{PM}_{1}<5 \mu \mathrm{g} \mathrm{m}^{-3}\right)$. This decrease was more pronounced for AA and WREG compared with 


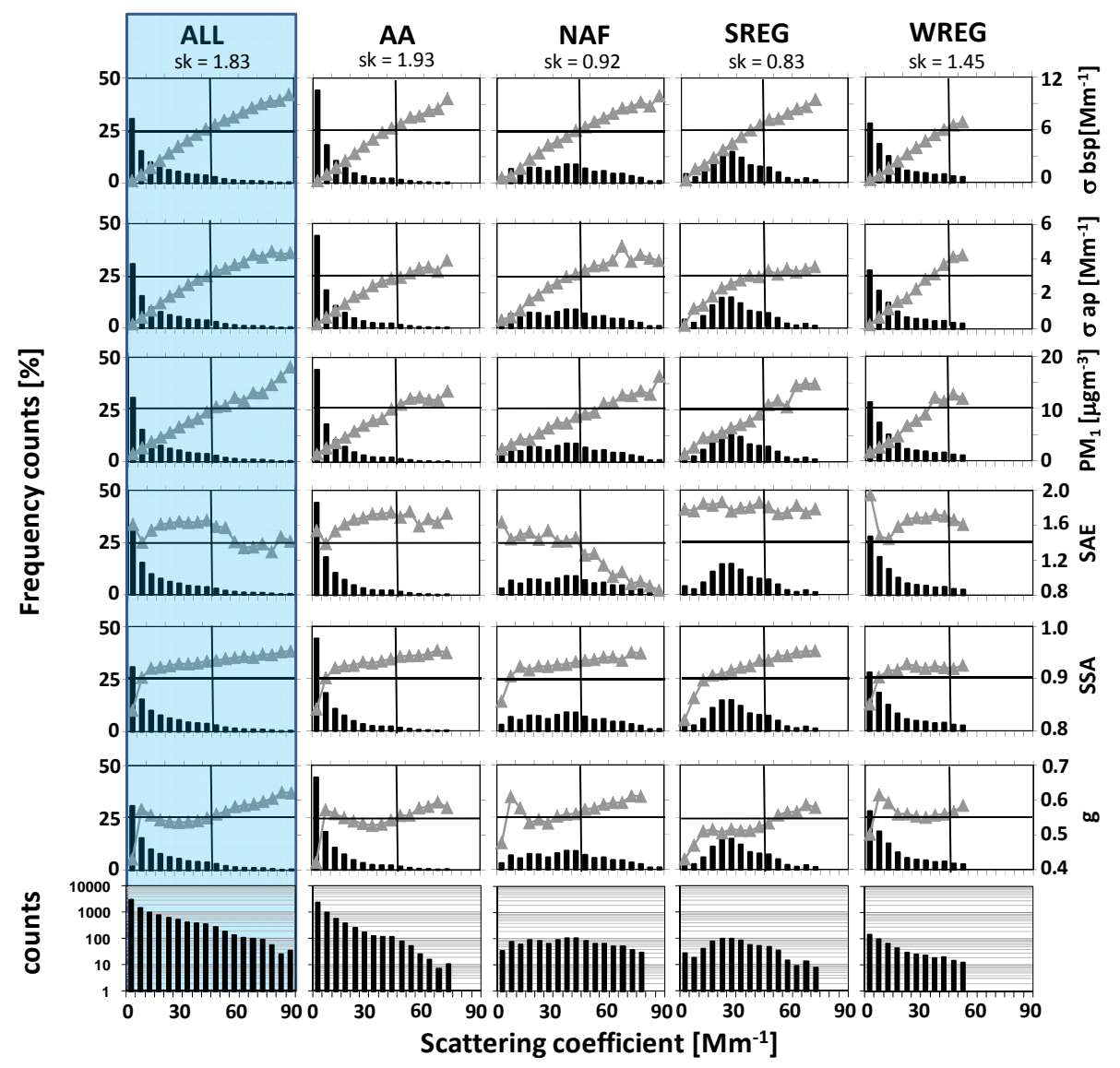

Figure 6. Correlation between the frequency distribution of aerosol scattering coefficients $\left(\sigma_{\mathrm{sp}}\right)$ at $635 \mathrm{~nm}$ and backscattering coefficient $\left(\sigma_{\mathrm{bsp}}\right.$ at $635 \mathrm{~nm})$, absorption coefficient $\left(\sigma_{\text {ap }}\right.$ at $\left.637 \mathrm{~nm}\right), \mathrm{PM}_{1}$ concentrations $\left(\mathrm{PM}_{1}\right)$, asymmetry parameter $(g$ at $635 \mathrm{~nm})$, scattering Ångström exponent (SAE, 450-635 nm) and single-scattering albedo (SSA at $635 \mathrm{~nm}$ ). Correlations are presented for all data (ALL) and for the different atmospheric scenarios (Atlantic advection, AA; Saharan dust outbreaks, NAF; summer regional recirculation scenario, SREG; and winter anticyclonic scenario, WREG). Frequency count (\%) and the absolute number of hourly values (counts) in each been are reported.

NAF and SREG (Fig. 6). However, under very low $\mathrm{PM}_{1}$ concentrations at MSC $\left(\mathrm{PM}_{1}<1.5 \mu \mathrm{g} \mathrm{m}^{-3}\right) \mathrm{SSA}$ and $g$ reached very low values around 0.84 and 0.43 (ALL in Fig. 6), respectively, whereas the SAE increased. These low PM conditions at MSC were associated with the prevalence of small particles with relatively higher absorption properties irrespective of the scenario considered. Low values of SSA at very low aerosol loading have been observed in AND2011 and associated with an aerosol mixture in which large scattering aerosol particles have been preferentially removed (e.g. by cloud scavenging and/or deposition), leaving behind a relatively smaller and darker aerosol (e.g. AND2011; Berkowitz et al., 2011; Marcq et al., 2010; Targino et al., 2005; Sellegri et al., 2003).

\subsection{MAC and MSCS climatology}

Mean MAC, determined at Montsec as the errorweighted slope of the absorption-EC scatterplot, was $11.1 \pm 0.3 \mathrm{~m}^{2} \mathrm{~g}^{-1} \quad\left(R^{2}=0.82\right)$. Given that $\sigma_{\text {ap }}$ and $\mathrm{EC}$ concentrations measurements have been available since the end of 2009, the mean MAC presented here was calculated over the period November 2009-June 2013 (384 sample pairs on $24 \mathrm{~h}$ basis). Mean MSCS at $635 \mathrm{~nm}$ (228 sample pairs) was $2.5 \pm 1.3 \mathrm{~m}^{2} \mathrm{~g}^{-1}$. MSCS at $525 \mathrm{~nm}$ and $450 \mathrm{~nm}$ are reported in Table 2. On average, lower MAC values were observed during AA $\left(9.7 \pm 0.7 \mathrm{~m}^{2} \mathrm{~g}^{-1}, R^{2}=0.77\right)$ and WREG $\left(9.4 \pm 1.0 \mathrm{~m}^{2} \mathrm{~g}^{-1}, R^{2}=0.88\right)$ scenarios compared to NAF $\left(11.9 \pm 0.7 \mathrm{~m}^{2} \mathrm{~g}^{-1}, R^{2}=0.61\right)$ and SREG $\left(12.6 \pm 1.0 \mathrm{~m}^{2} \mathrm{~g}^{-1}, R^{2}=0.74\right)$ scenarios. Similarly, a low MSCS was on average observed during AA and WREG $\left(2.0 \pm 1.1 \mathrm{~m}^{2} \mathrm{~g}^{-1}\right.$ and $1.5 \pm 0.6 \mathrm{~m}^{2} \mathrm{~g}^{-1}$, respectively, at $635 \mathrm{~nm}$ ), whereas MSCS was higher during NAF and SREG $\left(3.7 \pm 1.4 \mathrm{~m}^{2} \mathrm{~g}^{-1}\right.$ and $3.5 \pm 0.7 \mathrm{~m}^{2} \mathrm{~g}^{-1}$, respectively). The non-parametric Kruskal-Wallis test was used for testing the equality of medians among the four selected categories (scenarios). The difference between the NAF and SREG medians was not statistically significant $(p>0.5)$ for both MAC and MSCS. The same was observed for the AA and WREG medians $(p>0.3)$. Conversely, statistically 

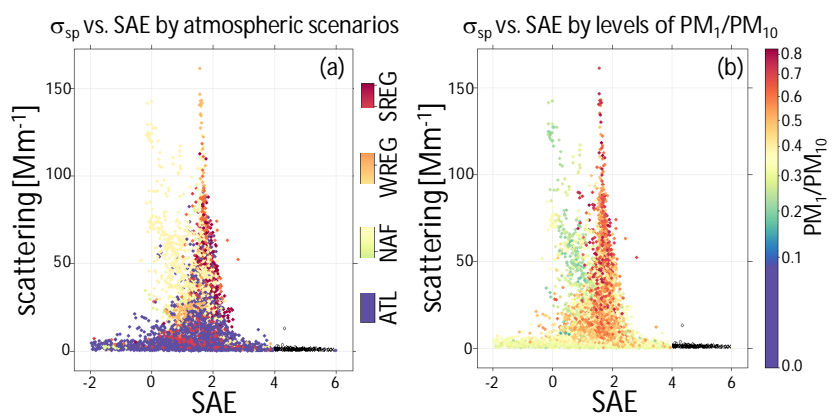

Figure 7. Scattering coefficient $\left(\sigma_{\mathrm{sp}}\right)$ distribution at $635 \mathrm{~nm}$ as a function of the scattering Ångström exponent (SAE) by atmospheric scenarios (a) and by levels of $\mathrm{PM}_{1} / \mathrm{PM}_{10}$ ratio (b). Dark data points indicate $\mathrm{SAE}>4$.

significant differences $(p<0.001)$ were observed between the medians calculated for WREG and AA and those calculated for NAF and SREG. The higher MAC and MSCS under NAF and SREG compared to AA and WREG were likely due to differences in particles' origin and particle properties during these scenarios. The SREG scenario is a summer scenario (cf. Fig. 8) which favours the recirculation and aging of pollutants in the WMB. Several publications have shown higher sulfate (e.g. Pey et al., 2009; Querol et al., 1999) and organic matter concentrations (e.g. Querol et al., 2013; Pandolfi et al., 2014) in summer compared to winter in the WMB at regional and remote levels. The summer sulfate and organic matter maxima were due to higher temperatures and increased photochemistry in the atmosphere enhancing the $\mathrm{SO}_{2}$ oxidation and the formation of secondary organic aerosols from biogenic emissions from vegetation (Seco et al., 2011).

Moreover, Ripoll et al. (2014) have shown higher concentrations of BC particles in the warmer months at MSC attributed to the impact of the SREG episodes and to the higher occurrence of wildfires in North Africa and/or in the WMB (Cristofanelli et al., 2009). Once formed, these particles can recirculate and age under the SREG scenario in the WMB. On the other hand, the NAF scenarios, which are more frequent in summer in the WMB (Pey et al., 2013), increase the concentration of mineral dust in the atmosphere. Moreover, Rodríguez et al. (2011) and Ripoll et al. (2014) have shown that pollutants such as sulfate and BC may be transported together with dust across the WMB during NAF episodes.

The mixing of $\mathrm{BC}$ particles with other chemical components, such as sulfate and organics, has the potential to increase the absorption properties of $\mathrm{BC}$ particles (e.g. Bond et al., 2013) and could explain the higher MAC observed at MSC during NAF and SREG. At the same time, the MSCS was also higher during NAF and SREG, indicating higher scattering efficiency of PM. Similar dependence of the MAC with atmospheric scenarios was reported by Pandolfi et al. (2011) for the MSY station. An exception was ob-
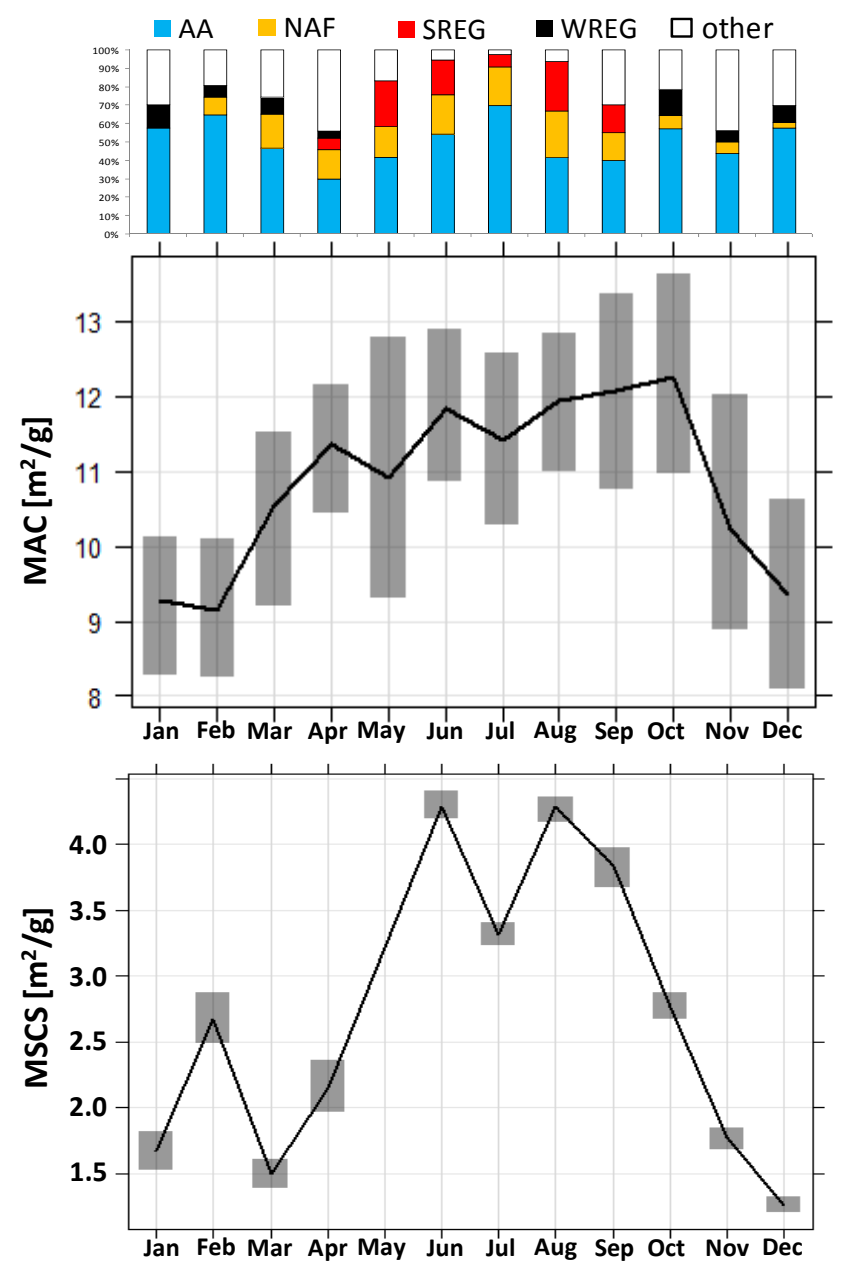

Figure 8. Monthly mean mass absorption cross section (MAC) and mass scattering cross section (MSCS) at MSC station and occurrence $(\%)$ of the main atmospheric scenarios (AA: Atlantic advections; NAF: Saharan dust outbreaks; SREG: summer regional recirculation scenarios; and WREG: winter anticyclonic scenarios). Bars represent $95 \%$ confidence intervals.

served for the MAC calculated at Montseny during WREG, which was the highest compared to AA, SREG and NAF. The likely reason for the different MAC at MSC and MSY under WREG was the lower altitude of the MSY station, which was often within the polluted PBL under WREG winter scenarios (i.e. Pandolfi et al., 2014), whereas the MSC was above.

As a consequence of the observed variations of MAC and MSCS as a function of the four considered season-dependent scenarios, the MAC and MSCS at MSC showed a clear annual cycle, with the lowest values observed in winter and the highest in summer (Fig. 8). Similar seasonal dependence of the MAC with higher values in summer was observed at the Jungfraujoch high-alpine site (Cozic et al., 2008). 


\section{Conclusions}

The measurements of aerosol optical properties presented in this work and performed at the remote Montsec site (MSC; $42^{\circ} 3^{\prime} \mathrm{N}, 0^{\circ} 44^{\prime} \mathrm{E}, 1570 \mathrm{~m}$ a.s.l.) add useful information on the limited amount of in situ aerosol optical data obtained at high-altitude/mountaintop sites worldwide. The aerosol scattering measurements performed at MSC located this site in the medium/upper range of values reported for other mountaintop sites in Europe (EU). The frequent African dust (NAF) outbreaks and regional recirculation (SREG) scenarios, typical of the WMB in spring/summer, were mainly responsible for these relatively high values. Moreover, the lower altitude of MSC station compared with other mountaintop sites and the strong summer insolation in the Mediterranean regions, favouring the development of thermally driven upslope winds, may have also contributed to the relatively higher scattering observed at MSC. The mean scattering at MSC during the NAF and SREG scenarios was close to the values measured at a regional background station (Montseny, $720 \mathrm{~m}$ a.s.l.), thus demonstrating the potential of these two summer atmospheric scenarios in polluting the whole lower troposphere in the western Mediterranean. As a consequence, in spring and summer no clear diurnal cycles were observed for the extensive aerosol optical properties due to the presence of polluted layer at the MSC altitude. Thus, the diurnal variation of scattering at MSC during spring and summer was subject to synoptic circulation, which partially masked the mountain breezes and the dynamics transport at a more local scale. Conversely, during Atlantic advection (AA) and winter regional anticyclonic (WREG) episodes, mainly registered during the cold season, the extensive aerosol properties at MSC were considerably lower compared to Montseny and the highest diurnal cycle amplitudes were observed. The AA scenario in the WMB is typically characterized by high wind speed with air masses coming from the Atlantic Ocean, thus favouring the dispersion of the accumulated pollution with consequent reduction of the concentrations of pollutants, which is more effective at remote levels. The WREG scenario is mainly characterized by weak synoptic winds leading to stagnation of air masses and to the accumulation and aging of pollutants over the region, whereas the PBL height mostly determines the dilution of pollutants around the emission sources and the degree of pollution at more elevated/regional areas in the WMB. Absorption at MSC was not as high as scattering compared with most of measurements in EU, thus leading to relatively higher single-scattering albedo (SSA) compared with EU data. Conversely, the scattering Ångström exponent (SAE) and backscatter-to-scatter ratios $(B / S)$ were in the middle of the corresponding EU ranges.

All the extensive aerosol properties measured at MSC showed relatively lower medians when MSC was in the free troposphere (FT data) compared with the whole database (all data). These decreases were clearly seasonal at the MSC site, with the highest and statistically significant FT- vs. all-data difference observed in winter and the lowest (and not statistically significant) in spring/summer. The frequent NAF and SREG scenarios in summer, and the less frequent FT conditions due to higher boundary layer, explained the lower FT- vs. all-data differences observed in summer compared to winter.

The aerosol optical measurements performed demonstrated that the MSC measurement site provides reliable information for a suitable characterization of the main synoptic meteorological patterns affecting the region. Clear differences were observed between NAF and SREG scenarios in terms of intensive aerosol optical properties. SAE during NAF was the lowest, indicating the presence of larger particles, and was clearly anticorrelated with the intensity of Saharan dust outbreaks, whereas nearly constant and higher SAE was measured under SREG, indicating an aerosol mode dominated by finer particles. Correspondingly, the asymmetry parameter was higher during NAF compared to SREG. The analysis of the relationships between scattering and other extensive/intensive aerosol properties measured at MSC showed a scattering-absorption slope in the lower range of slopes calculated worldwide, indicating that the MSC site is dominated by dust aerosols at high aerosol loading. As a consequence, SSA increased nearly monotonically with increasing scattering.

The MAC estimated at MSC showed a clear annual cycle, with higher values in summer when the occurrence of NAF and SREG scenarios favoured the presence of polluted atmospheric layers containing aged $\mathrm{BC}$ particles likely mixed with other chemical components such as organics and sulfate. These summer conditions were also linked with higher scattering efficiency of PM.

Acknowledgements. This work was supported by the MINECO (Spanish Ministry of Economy and Competitiveness), the MAGRAMA (Spanish Ministry of Agriculture, Food and Environment) and FEDER funds: the projects PRISMA (CGL2012-39623C02/00) and VAMOS (CLG2010-19464). The research received funding from the European Union Seventh Framework Programme (FP7/2007-2013) ACTRIS under grant agreement no. 262254. M. Pandolfi was funded by the JAE-Doc CSIC programme, co-funded by the European Social Fund (ESF). The authors wish to thank D. C. Carslaw and K. Ropkins for providing the Openair software used in this paper (Carslaw and Ropkins, 2012; Carslaw, 2012). The authors wish to thank A. Tobias for the statistical analysis related with Fig. 5. The authors are grateful for the use of the HYSPLIT model, SKIRON, BSC-DREAM and NRL-NAAPS aerosol maps, NCEP/NCAR meteorological database NOAA NAO index data, and image products from MODIS and SeaWiFs NASA satellites used in this publication. The authors would like to extend their gratitude to the personnel from the OAdM. We would also like to express our gratitude to METEOCAT for the meteorological data.

Edited by: S. Gilardoni 


\section{References}

Aaltonen, V., Lihavainen, H., Kerminen, V.-M., Komppula, M., Hatakka, J., Eneroth, K., Kulmala, M., and Viisanen, Y.: Measurements of optical properties of atmospheric aerosols in Northern Finland, Atmos. Chem. Phys., 6, 1155-1164, doi:10.5194/acp-6-1155-2006, 2006.

Anderson, T. L. and Ogren, J. A.: Determining Aerosol Radiative Properties Using the TSI 3563 Integrating Nephelometer, Aerosol Sci. Tech., 29, 57-69, 1998.

Andrews, E., Sheridan, P. J., Fiebig, M., McComiskey, A., Ogren, J. A., Arnott, P., Covert, D., Elleman, R., Gasparini, R., Collins, D., Jonsson, H., Schmid, B., and Wang, J.: Comparison of methods for deriving aerosol asymmetry parameter, J. Geophys. Res. Atmos., 111, D05S04, doi:10.1029/2004JD005734, 2006.

Andrews, E., Ogren, J. A., Bonasoni, P., Marinoni, A., Cuevas, E., Rodríguez, S., Sun, J. Y., Jaffe, D. A., Fischer, E. V., Baltensperger, U., Weingartner, E., Collaud Coen, M., Sharma, S., Macdonald, A. M., Leaitch, W. R., Lin, N.-H., Laj, P., Arsov, T., Kalapov, I., Jefferson, A., and Sheridan, P.: Climatology of aerosol radiative properties in the free troposphere, Atmos. Res., 102, 365-393, doi:10.1016/j.atmosres.2011.08.017, 2011.

Arnott, W. P., Moosmüller, H., Sheridan, P. J., Ogren, J. A., Raspet, R., Slaton, W. V., Hand, J. L., Kreidenweis, S. M., and Collett Jr., J. L.: Photoacoustic and Filter-Based Ambient Aerosol Light Absorption Measurements: Instrument Comparisons and the Role of Relative Humidity, J. Geophys. Res., 108, 4034, doi:10.1029/2002JD002165, 2003.

Arnott, W. P., Hamasha, K., Moosmüller, H., Sheridan, P. J., and Ogren, J. A.: Towards Aerosol Light Absorption Measurements with a 7-wavelength Aethalometer: Evaluation with a Photoacoustic Instrument and 3 wavelength Nephelometer, Aerosol Sci. Tech., 39, 17-29, 2005.

Berkowitz, C., Berg, L. K., Yu, X.-Y., Alexander, M. L., Laskin, A., Xie, Y., Jobson, B. T., Andrews, E., and Ogren, J.: A statistical overview of aerosol optical, chemical and physical measurements at a coastal northern California site during the summer of 2005, Atmos. Environ., 45, 2559-2568, doi:10.1016/j.atmosres.2011.08.017, 2011.

Bodhaine, B.: Aerosol measurements at four background sites, J. Geophys. Res. 88, 10753-10768, doi:10.1029/JC088iC15p10753, 1983.

Bodhaine, B.: Aerosol absorption measurements at Barrow, Mauna Loa and the South Pole. J. Geophys. Res., 100, 8967-8975, doi:10.1029/95JD00513, 1995.

Bond, T. C. and Bergstrom, R. W.: Light absorption by carbonaceous particles: An investigative review, Aerosol Sci. Tech., 40, 27-67, doi:10.1080/02786820500421521, 2006.

Bond, T. C., Doherty, S. J., Fahey, D. W., Forster, P. M., Berntsen, T., DeAngelo, B. J., Flanner, M. G., Ghan, S., Kärcher, B., Koch, D., Kinne, S., Kondo, Y., Quinn, P. K., Sarofim, M. C., Schultz, M. G., Schulz, M., Venkataraman, C., Zhang, H., Zhang, S., Bellouin, N., Guttikunda, S. K., Hopke, P. K., Jacobson, M. Z., Kaiser, J. W., Klimont, Z., Lohmann, U., Schwarz, J. P., Shindell, D., Storelvmo, T., Warren S. G., and Zender, C. S.: Bounding the role of black carbon in the climate system: A scientific assessment, J. Geophys. Res. 118, 11, 5380-5552, doi:10.1002/jgrd.50171, 2013.
Carslaw, D. C.: The openair manual - open-source tools for analysing air pollution data, Manual for version 0.7-0, King's College, London, 2012.

Carslaw, D. C. and Ropkins, K.: openair - an R package for air quality data analysis, Environ. Modell. Softw., 27-28, 52-61, 2012.

Cavalli, F., Viana, M., Yttri, K. E., Genberg, J., and Putaud, J.-P.: Toward a standardised thermal-optical protocol for measuring atmospheric organic and elemental carbon: the EUSAAR protocol, Atmos. Meas. Tech., 3, 79-89, doi:10.5194/amt-3-79-2010, 2010.

Cermak, J., Wild, M., Knutti, R., Mishchenko, M. I., and Heidinger A. K.: Consistency of global satellite-derived aerosol and cloud data sets with recent brightening observations, Geophys. Res. Lett., 37, L21704, doi:10.1029/2010g1044632, 2010.

Collaud Coen, M., Weingartner, E., Schaub, D., Hueglin, C., Corrigan, C., Henning, S., Schwikowski, M., and Baltensperger, U. Saharan dust events at the Jungfraujoch: detection by wavelength dependence of the single scattering albedo and first climatology analysis, Atmos. Chem. Phys., 4, 2465-2480, doi:10.5194/acp4-2465-2004, 2004.

Collaud Coen, M., Weingartner, E., Nyeki, S., Cozic, J., Henning, S., Verheggen, B., Gehrig, R., and Baltensperger, U.: Long-term trend analysis of aerosol variables at the highalpine site Jungfraujoch, J. Geophys. Res., 112, D13213, doi:10.1029/2006JD007995, 2007.

Collaud Coen, M., Weingartner, E., Furger, M., Nyeki, S., Prévôt, A. S. H., Steinbacher, M., and Baltensperger, U.: Aerosol climatology and planetary boundary influence at the Jungfraujoch analyzed by synoptic weather types, Atmos. Chem. Phys., 11, 5931-5944, doi:10.5194/acp-11-5931-2011, 2011.

Cozic, J., Verheggen, B., Weingartner, E., Crosier, J., Bower, K. N., Flynn, M., Coe, H., Henning, S., Steinbacher, M., Henne, S., Collaud Coen, M., Petzold, A., and Baltensperger, U.: Chemical composition of free tropospheric aerosol for PM1 and coarse mode at the high alpine site Jungfraujoch, Atmos. Chem. Phys. 8, 407-423, doi:10.5194/acp-8-407-2008, 2008.

Cristofanelli, P., Marinoni, A., Arduini, J., Bonafè, U., Calzolari, F., Colombo, T., Decesari, S., Duchi, R., Facchini, M. C., Fierli, F., Finessi, E., Maione, M., Chiari, M., Calzolai, G., Messina, P., Orlandi, E., Roccato, F., and Bonasoni, P.: Significant variations of trace gas composition and aerosol properties at $\mathrm{Mt}$. Cimone during air mass transport from North Africa - contributions from wildfire emissions and mineral dust, Atmos. Chem. Phys., 9, 4603-4619, doi:10.5194/acp-9-4603-2009, 2009.

Delene, D. J. and Ogren, J. A.: Variability of aerosol optical properties at four North American surface monitoring sites, J. Atmos. Sci., 59, 1135-1150, 2002.

Fernández-Camacho, R., Rodríguez, S., de la Rosa, J., Sánchez de la Campa, A. M., Viana, M., Alastuey, A., and Querol, X.: Ultrafine particle formation in the inland sea breeze airflow in Southwest Europe, Atmos. Chem. Phys., 10, 9615-9630, doi:10.5194/acp10-9615-2010, 2010.

Fierz-Schmidhauser, R., Zieger, P., Gysel, M., Kammermann, L., DeCarlo, P. F., Baltensperger, U., and Weingartner, E.: Measured and predicted aerosol light scattering enhancement factors at the high alpine site Jungfraujoch, Atmos. Chem. Phys., 10, 2319 2333, doi:10.5194/acp-10-2319-2010, 2010.

Gangoiti, G., Millán, M. M., Salvador, R., and Mantilla E.: LongRange transport and recirculation of pollutants in the western 
Mediterranean during the project Regional Cycles of Air Pollution in the west-central Mediterranean Area, Atmos. Environ., 35, 6267-6276, 2001.

IPCC 2007, in: Climate Change 2007: The Physical Science Basis (Contribution of Working Group I to the Fourth Assessment Report of the Intergovernmental Panel on Climate Change) edited by: Solomon, S., Qin, D. Manning, M., Chen, Z., Marquis, M., Averyt, K. B., Tignor, M., and Miller, H. L., Cambridge Univ. Press, New York, USA, 131-217, 2007.

IPCC 2013, in Climate Change 2013: The Physical Science Basis. Working Group I contribution to the IPCC fifth assessment report. Final Draft Underlying Scientific-Technical Assessment, Cambridge University Press, Cambridge, United Kingdom and New York, NY, USA, 2013.

Jorba, O., Pandolfi, M., Spada, M., Baldasano, J. M., Pey, J., Alastuey, A., Arnold, D., Sicard, M., Artinano, B., Revuelta, M. A., and Querol, X.: Meteorological overview and transport patterns of the DAURE field campaign: link to PM observations, Atmos. Environ., 77, 607-620, 2013.

JRC Report: Measurement of Elemental and Organic Carbon in Europe, Scientific and Technical Reports, EUR 23922 EN-2009, Joint Research Center, Ispra, Italy, 2009.

Laj, P., Klausen, J., Bilde, M., Plaß-Duelmer, C., Pappalardo, G., Clerbaux, C., Baltensperger, U., Hjorth, J., Simpson, D., Reimann, S., Coheur, P.-F., Richter, A., De Mazière, M., Rudich, Y., McFiggans, G., Torseth, K., Wiedensohler, A., Morin, S., Schulz, M., Allan, J. D., Attié, J.-L., Barnes, I., Birmili, W., Cammas, J. P., Dommen, J., Dorn, H.-P., Fowler, D., Fuzzi, S., Glasius, M., Granier, C., Hermann, M., Isaksen, I. S. A., Kinne, S., Koren, I., Madonna, F., Maione, M., Massling, A., Moehler, O., Mona, L., Monks, P. S., Müller, D., Müller, T., Orphal, J., Peuch, V.-H., Stratmann, F., Tanré, D., Tyndall, G., Abo Riziq, A., Van Roozendael, M., Villani, P., Wehner, B., Wex, H., and Zardini, A. A.: Measuring atmospheric composition change, Atmos. Environ., 43, 5351-5414, doi:10.1016/j.atmosenv.2009.08.020, 2009.

Marcq, S., Laj, P., Roger, J. C., Villani, P., Sellegri, K., Bonasoni, P., Marinoni, A., Cristofanelli, P., Verza, G. P., and Bergin, M.: Aerosol optical properties and radiative forcing in the high Himalaya based on measurements at the Nepal Climate Observatory-Pyramid site (5079 m a.s.1.), Atmos. Chem. Phys., 10, 5859-5872, doi:10.5194/acp-10-5859-2010, 2010.

Marinoni, A., Cristofanelli, P., Calzolari, F., Roccato, F., Bonafe, U., and Bonasoni, P.: Continuous measurements of aerosol physical parameters at the Mt. Cimone GAW station (2165 m a.s.l., Italy), Sci. Total. Environ., 391, 241-251, 2008.

McKendry, I., Strawbridge, K., Karumudi, M. L., O’Neill, N., Macdonald, A. M., Leaitch, R., Jaffe, D., Cottle, P., Sharma, S., Sheridan, P., and Ogren, J.: Californian forest fire plumes over Southwestern British Columbia: lidar, sunphotometry, and mountaintop chemistry observations, Atmos. Chem. Phys., 11, 465-477, doi:10.5194/acp-11-465-2011, 2011.

Millán, M. M., Artiñano, B., Alonso, L., Castro, M., FernándezPatier, R., and Goberna, J.: Meso-meteorological Cycles of Air Pollution in the Iberian Peninsula, (MECAPIP), Contract EV4V0097-E, Air Pollution Research Report 44, (Eur No. 14834) CEC-DG XII/E-1, Rue de la Loi, 200, 1040, Bruselas, 219 pp., 1992.

Millán, M. M., Salvador, R., Mantilla, E., and Kallos, G.: Photooxidant dynamics in the Mediterranean basin in summer: Results from European research projects, J. Geophys. Res., 102, 88118823, doi:10.1029/96JD03610, 1997.

Müller, T., Laborde, M., Kassell, G., and Wiedensohler, A.: Design and performance of a three-wavelength LED-based total scatter and backscatter integrating nephelometer, Atmos. Meas. Tech., 4, 1291-1303, doi:10.5194/amt-4-1291-2011, 2011a.

Müller, T., Henzing, J. S., de Leeuw, G., Wiedensohler, A., Alastuey, A., Angelov, H., Bizjak, M., Collaud Coen, M., Engström, J. E., Gruening, C., Hillamo, R., Hoffer, A., Imre, K., Ivanow, P., Jennings, G., Sun, J. Y., Kalivitis, N., Karlsson, H., Komppula, M., Laj, P., Li, S.-M., Lunder, C., Marinoni, A., Martins dos Santos, S., Moerman, M., Nowak, A., Ogren, J. A., Petzold, A., Pichon, J. M., Rodriquez, S., Sharma, S., Sheridan, P. J., Teinilä, K., Tuch, T., Viana, M., Virkkula, A., Weingartner, E., Wilhelm, R., and Wang, Y. Q.: Characterization and intercomparison of aerosol absorption photometers: result of two intercomparison workshops, Atmos. Meas. Tech., 4, 245-268, doi:10.5194/amt-4-245-2011, 2011 b.

Nyeki, S., Baltensperger, U., Colbeck, I., Jost, D. T., Weingartner, E., Gaggeler, H. W.: The Jungfraujoch high-alpine research station $(3454 \mathrm{~m})$ as a background clean continental site for the measurement of aerosol parameters, J. Geophys. Res., 103, 60976107, doi:10.1029/97JD03123, 1998.

Ogren, J. A., Andrews, E., McComiskey, A., Sheridan, P., Jefferson, A., and Fiebig, M.: New insights into aerosol asymmetry parameter, in: Proceedings of the 16th ARM Science Team Meeting, Albuquerque, NM, USA, 2006.

Pandolfi, M., Cusack, M., Alastuey, A., and Querol, X.: Variability of aerosol optical properties in the Western Mediterranean Basin, Atmos. Chem. Phys., 11, 8189-8203, doi:10.5194/acp-11-81892011, 2011.

Pandolfi, M., Querol, X., Alastuey, A., Jimenez, J. L., Jorba, O., Day, D., Ortega, A., Cubison, M. J., Comerón, A., Sicard, M., Mohr, C., Prévôt, A. S. H., Minguillón, M. C., Pey, J., Baldasano, J. M., Burkhart, J. F., Seco, R., Peñuelas, J., van Drooge, B. L., Artiñano, B., Di Marco, C., Nemitz, E., Schallhart, S., Metzger, A., Hansel, A., Lorente, J., Ng, S., Jayne, J., and Szidat, S.: Effects of sources and meteorology on particulate matter in the Western Mediterranean Basin: An overview of the DAURE campaign, J. Geophys. Res. Atmos., 119, 4978-5010, doi:10.1002/2013JD021079, 2014.

Pereira, S. N., Wagner, F., and Silva, A. M.: Seven years of measurements of aerosol scattering properties, near the surface, in the southwestern Iberia Peninsula, Atmos. Chem. Phys., 11, 1729, doi:10.5194/acp-11-17-2011, 2011.

Pérez, C., Sicard, M., Jorba, O., Comerón, A., and Baldasano J. M.: Summertime re-circulations of air pollutants over the northeastern Iberian coast observed from systematic EARLINET lidar measurements in Barcelona, Atmos. Environ., 38, 3983-4000, doi:10.1016/j.atmosenv.2004.04.010, 2004.

Pérez, N., Pey, J., Castillo, S., Viana, M., Alastuey, A., and Querol, $\mathrm{X}$.: Interpretation of the variability of levels of regional background aerosols in the Western Mediterranean, Sci. Total Environ., 407, 527-540, doi:10.1016/j.scitotenv.2008.09.006, 2008.

Petzold, A. and Schönlinner, M.: Multi-angle absorption photometry - a new method for the measurement of aerosol light absorption and atmospheric black carbon, J. Aerosol Sci., 35, 421-441, doi:10.1016/j.jaerosci.2003.09.005, 2004. 
Pey, J., Pérez, N., Castillo, S., Viana, M., Moreno, T., Pandolfi, M., López-Sebastián, J. M., Alastuey, A., and Querol, X.: Geochemistry of regional background aerosols in the Western Mediterranean, Atmos. Res., 94, 422-435, doi:10.1016/j.atmosres.2009.07.001, 2009.

Pey, J., Querol, X., Alastuey, A., Forastiere, F., and Stafoggia, M.: African dust outbreaks over the Mediterranean Basin during 2001-2011: PM10 concentrations, phenomenology and trends, and its relation with synoptic and mesoscale meteorology, Atmos. Chem. Phys., 13, 1395-1410, doi:10.5194/acp-13-13952013, 2013.

Polissar, A. V., Hopke, P. K., Malm, W. C., and Sisler, J. F.: Atmospheric aerosols over Alaska: 2. Elemental Composition and Sources, J. Geophys. Res., 103, 19045-19057, doi:10.1029/98JD01212, 1998.

Querol, X., Alastuey, A., Lopez-soler, A., Plana, F. and Puicercus, J. A.: Daily evolution of sulphate aerosols in a rural area, northeastern Spain - elucidation of an atmospheric reservoir effect, Environ. Pollut., 105, 397-407, doi:10.1016/S0269-7491(99)000378, 1999.

Querol, X., Pey, J., Minguillón, M. C., Pérez, N., Alastuey, A., Viana, M., Moreno, T., Bernabé, R. M., Blanco, S., Cárdenas, B., Vega, E., Sosa, G., Escalona, S., Ruiz, H., and Artíñano, B.: PM speciation and sources in Mexico during the MILAGRO-2006 Campaign, Atmos. Chem. Phys., 8, 111-128, doi:10.5194/acp8-111-2008, 2008.

Querol, X., Alastuey, A., Pey, J., Cusack, M., Pérez, N., Mihalopoulos, N., Theodosi, C., Gerasopoulos, E., Kubilay, N., and Koçak, M.: Variability in regional background aerosols within the Mediterranean, Atmos. Chem. Phys., 9, 4575-4591, doi:10.5194/acp-9-4575-2009, 2009.

Querol, X., Alastuey, A., Viana, M., Moreno, T., Reche, C., Minguillón, M. C., Ripoll, A., Pandolfi, M., Amato, F., Karanasiou, A., Pérez, N., Pey, J., Cusack, M., Vázquez, R., Plana, F., Dall'Osto, M., de la Rosa, J., Sánchez de la Campa, A., Fernández-Camacho, R., Rodríguez, S., Pio, C., AladosArboledas, L., Titos, G., Artíñano, B., Salvador, P., García Dos Santos, S., and Fernández Patier, R.: Variability of carbonaceous aerosols in remote, rural, urban and industrial environments in Spain: implications for air quality policy, Atmos. Chem. Phys., 13, 6185-6206, doi:10.5194/acp-13-6185-2013, 2013.

Quinn, P. K. and Bates, T. S.: Regional aerosol properties: Comparisons of boundary layer measurements from ACE 1, ACE 2, Aerosols99, INDOEX, ACE Asia, TARFOX, and NEAQS, J. Geophys. Res., 110, D14202, doi:10.1029/2004JD004755, 2005.

Reche, C., Querol, X., Alastuey, A., Viana, M., Pey, J., Moreno, T., Rodríguez, S., González, Y., Fernández-Camacho, R., de la Rosa, J., Dall'Osto, M., Prévôt, A. S. H., Hueglin, C., Harrison, R. M., and Quincey, P.: New considerations for PM, Black Carbon and particle number concentration for air quality monitoring across different European cities, Atmos. Chem. Phys., 11, 6207-6227, doi:10.5194/acp-11-6207-2011, 2011.
Ripoll, A., Pey, J., Minguillón, M. C., Pérez, N., Pandolfi, M., Querol, X., and Alastuey, A.: Three years of aerosol mass, black carbon and particle number concentrations at Montsec (southern Pyrenees, 1570 ma.s.1.), Atmos. Chem. Phys., 14, 4279-4295, doi:10.5194/acp-14-4279-2014, 2014.

Rodríguez, S., Querol, X., Alastuey, A., Kallos, G., and Kakaliagou, O.: Saharan dust contributions to $\mathrm{PM}_{10}$ and TSP levels in Southern and Eastern Spain, Atmos. Environ., 35, 2433-2447, 2001.

Rodríguez, S., Querol, X., Alastuey, A., Viana, M. M., Alarcón, M., Mantilla, E., and Ruiz, C. R.: Comparative $\mathrm{PM}_{10}-\mathrm{PM}_{2.5}$ source contribution study at rural, urban and industrial sites during PM episodes in Eastern Spain, Sci. Total Environ., 26, 95113, doi::10.1016/S0048-9697(03)00411-X, 2004.

Rodríguez, S., Alastuey, A., Alonso-Pérez, S., Querol, X., Cuevas, E., Abreu-Afonso, J., Viana, M., Pérez, N., Pandolfi, M., and de la Rosa, J.: Transport of desert dust mixed with North African industrial pollutants in the subtropical Saharan Air Layer, Atmos. Chem. Phys., 11, 6663-6685, doi:10.5194/acp-11-66632011, 2011.

Schuster, G. L., Dubovik, O., and Holben, B. N.: Ångström exponent and bimodal aerosol size distributions, J. Geophys. Res., 111, D07207, doi:101029/2005JD006328, 2006.

Seco, R., Peñuelas, J., Filella, I., Llusià, J., Molowny-Horas, R., Schallhart, S., Metzger, A., Müller, M., and Hansel, A.: Contrasting winter and summer VOC mixing ratios at a forest site in the Western Mediterranean Basin: the effect of local biogenic emissions, Atmos. Chem. Phys., 11, 13161-13179, doi:10.5194/acp11-13161-2011, 2011.

Sellegri, K., Laj, P., Dupuy, R., Legrand, M., Preunkert, S., and Putaud, J.-P.: Size-dependent scavenging efficiencies of multicomponent atmospheric aerosols in clouds, J. Geophys. Res., 108, 4334, doi:10.1029/2002JD002749, D11, 2003.

Singh, R. P., Dey, S., Tripathi, S. N., Tare, V., and Holben, B. N.: Variability of aerosol parameters over Kanpur city, northern India, J. Geophys. Res., 109, D23206, doi:10.1029/2004JD004966, 2004.

Targino, A. C., Noone, K. J., and Ostrom, E.: Airborne insitu characterization of dry aerosol optical properties in a multisource influenced marine region, Tellus B, 57, 247-260, doi:10.1111/j.1600-0889.2005.00147.x, 2005.

Vaisala Oyj.: Humidity Conversion Formulas, published by Vaisala, Helsinki, http://www.vaisala.com/Vaisala\%20Documents/ Application\%20notes/Humidity_Conversion_Formulas_ B210973EN-F.pdf (last access: 2014), 2013.

Venzac, H., Sellegri, K., Villani, P., Picard, D., and Laj, P.: Seasonal variation of aerosol size distributions in the free troposphere and residual layer at the puy de Dôme station, France, Atmos. Chem. Phys., 9, 1465-1478, doi:10.5194/acp-9-1465-2009, 2009. 